\title{
Sectors and the additionality effects of $R \& D$ tax credits: A cross-country microeconometric analysis
}

\author{
Bodas Freitas, I., Castellacci, F., Fontana, R., Malerba, F. and Vezzulli, A. \\ Research Policy \\ Forthcoming, 2017
}

\begin{abstract}
Do the additionality effects of R\&D tax credits vary across sectors? The paper presents a microeconometric analysis of this question for three countries: Norway, Italy and France. We use a panel of firm-level data from three waves of the Innovation Surveys carried out in these countries for 2004, 2006 and 2008. The study estimates input and output additionality effects of R\&D tax credits in each of these economies, and it investigates how these effects differ across sectors characterized by different $\mathrm{R} \& \mathrm{D}$ orientation and competition conditions. The results point out that firms in industries with high $\mathrm{R} \& \mathrm{D}$ orientation have on average higher propensity to apply to $\mathrm{R} \& \mathrm{D}$ fiscal incentives schemes and stronger input and output additionality effects. Output additionality is found to differ among the three examined countries.
\end{abstract}

Key words: R\&D policy; R\&D tax credits; input additionality; output additionality; Pavitt taxonomy; market concentration

JEL codes: H25, H32, O32, O38 


\section{Introduction}

More than 20 OECD countries currently support private R\&D investments through R\&D tax credits. In the presence of a $R \& D$ tax credit program, firms that are engaged in $R \& D$ activities can apply for direct reductions on the amount of tax to be paid, and in this way significantly reduce the costs of their existing $R \& D$ projects and/or expand their scale (OECD, 2010).

A large stream of applied research has investigated the effects of tax credits on firms' R\&D expenditures by employing firm-level data (Hall and Van Reenen, 2000; Parsons and Phillips, 2007; Arvanitis, 2013). This literature has mostly focused on the estimation of the input additionality effect, namely the increase in $R \& D$ expenditures caused by a tax incentive scheme vis-a-vis the counterfactual situation in which the firm does not receive any public support (Yang et al., 2012; Yohei, 2013). Only a very limited number of studies has so far attempted to estimate the output additionality effect, which measures the extent to which a given increase in a firm's $R \& D$ expenditures (generated by a tax credit) leads to an increase in a firm's innovation output (Czarnitzki et al., 2011; Cappelen et al., 2012; Takalo et al., 2013).

A general characteristic of the $R \& D$ tax credits literature is that most studies have estimated the average additionality parameter within a given national economy. However, while the average additionality parameter provides a general indication about the effectiveness of R\&D tax credits programs, this figure per-se provides policy-makers with limited insights on its real effectiveness within an economy. The effects of R\&D policy may in fact be heterogeneous. Academic research should uncover the sources of heterogeneity in order to provide innovation policy-makers with a more thorough understanding for the formulation and revision of $\mathrm{R} \& \mathrm{D}$ tax credit programs in the future.

In this paper we focus on one specific source of heterogeneity: industrial sectors. The extant research on R\&D tax credits has paid relatively little attention to whether, and to what extent, additionality effects differ across sectors. Castellacci and Lie (2015) have recently carried out a meta-regression analysis of the $\mathrm{R} \& \mathrm{D}$ tax credits literature, pointing out that the size of the 
estimated additionality effects also depends on whether or not the studies controlled for industrylevel differences. This suggests that the analysis of sectoral differences in the additionality effects of R\&D tax credits does indeed represent an important aspect that deserves further investigation. One reason to expect cross-sectoral variation is that, as it has convincingly been shown in the field of innovation studies, sectors matter (Malerba, 2002). The sectoral context provides firms with a different set of technological and market opportunities and constraints that greatly shape the way in which firms organize their innovative activities, choose innovative strategies, and perform (Dosi, 1988). More specifically, as shown by Pavitt (1984), industries differ substantially in terms of the dominant innovation strategy adopted by firms, and in particular with respect to their $\mathrm{R} \& \mathrm{D}$ orientation, i.e. the extent to which formal $\mathrm{R} \& \mathrm{D}$ activities represent the main innovation strategy adopted by innovative companies (Castellacci, 2008). In addition to this, the literature on competition and innovation has for a long time studied the relationships between the degree of market competition and innovation and shown the importance of cross-industry differences in this respect (Breschi et al., 2000).

Building upon this literature, the present paper tackles two research questions related to cross industry differences. The first is whether or not the input and the output additionality of R\&D tax credits vary with an industry's R\&D orientation. The second question is whether sectorspecific competition conditions (and in particular the degree of market concentration) affect the input and the output additionality effects of R\&D tax credits.

To answer these questions, we perform a micro-econometric analysis for three countries: Norway, Italy and France. We use panel data on manufacturing firms from three waves of the Innovation Surveys carried out in these countries (referring to the years 2004, 2006 and 2008 respectively). The study estimates additionality effects of $R \& D$ tax credits in each of these economies by using a three-step estimation procedure previously employed by Czarnitzki and Hussinger (2004) and Cerulli and Poti (2012) (see also Czarnitzki and Delanote, 2014). In a nutshell, our results suggest that firms in industries with high R\&D orientation (and in particular 
in science-based and specialized suppliers) are on average more responsive to fiscal incentives to $\mathrm{R} \& \mathrm{D}$, especially in using these incentives and in increasing their $\mathrm{R} \& \mathrm{D}$ expenditures. We also find that output additionality differs considerably among the three examined countries.

The paper contributes to the literature in four respects. First and foremost, by explicitly investigating the role of the sectoral dimension, this paper creates a bridge between the $R \& D$ policy literature and the literature on sectoral patterns of innovation. Second, the study considers both the input additionality and the output additionality effects (the latter have typically been neglected in previous research on R\&D tax credits). Third, while most prior studies have focused on firm-level samples for a single economy, the present work combines micro-econometric evidence for three countries. Cross-country comparisons may shed light on the role of countryspecific aspects (and particularly the design of national R\&D policies) on the effects of fiscal incentives to R\&D. Finally, this paper suggests that R\&D tax credit programs, although usually horizontally defined (i.e. providing the same fiscal incentives to firms in all sectors of the economy), tend to benefit companies in different industries differently.

The paper is organized as follows: section 2 presents the main theoretical framework and develops the hypotheses; section 3 introduces the model specification, data and econometric methods; section 4 discusses the results; section 5 concludes the work and points out implications for policy and future research.

\section{Theoretical framework and hypotheses development}

Most of the literature that investigates the effects of tax credits on firms' R\&D expenditures has so far focused on input additionality effects. Input additionality is the extent to which a given amount of tax credits leads to an increase in a firm's R\&D expenditures, as compared to the situation in which a company does not receive any fiscal incentive (Wilson, 2009). 
Only a very limited number of studies in the R\&D tax credit literature have so far tried to estimate the output additionality effects (Takalo et al., 2013). The latter is the extent to which a given increase in a firm's R\&D expenditures generated by a tax credit leads to an increase in the firm's innovation output. Among the few studies that have examined output additionality, Czarnitzki et al. (2011) presented an empirical analysis focused on the new product performance of Canadian firms, and Cappelen et al. (2012) studied the innovation and patenting activity of Norwegian firms and their relation to the Norwegian tax credit scheme (SkatteFUNN).

A general limitation of the existing literature on $\mathrm{R} \& \mathrm{D}$ tax credits is that most studies have estimated regression models for the whole sample of observations, and have seldom investigated differences in the additionality effects across sectors. Only a limited number of studies have presented estimations for sub-samples of high- and low-tech industries, mostly done as robustness checks. For instance, Wang and Tsai (1998), Huang (2009) and Yang et al. (2012) focused on Taiwanese companies: they found that enterprises in the electronics sector are more responsive to fiscal incentives than firms in other manufacturing industries. Paff (2004 and 2005), Ho (2006) and Rao (2013) investigated the effects of the standard tax credit and the alternate incremental credit (AIC) in the US, highlighting substantial differences between high-tech and low-tech sectors. However, these studies have mostly treated sectoral differences as a secondary aspect: they have not investigated whether there is a systematic effect, and what sector-specific factors may explain these patterns (Castellacci and Lie, 2015). This is the research question that this paper intends to explore.

\subsection{Additionality effects and sectoral patterns of innovation}

Why should we expect the additionality effects of R\&D tax credits to differ across industries? To answer this question we draw upon two related branches of literature: one on technological trajectories and sectoral taxonomies, and the other on competition and innovation. 
The literature on technological trajectories and sectoral taxonomies has its origins in the work of Pavitt (1984). In this seminal paper, Pavitt identified three dimensions which characterize innovative activity: the main locus and source of innovation (i.e. where innovation takes place); which type of innovation is paramount and what is needed to innovate; the structure of the industry (i.e. concentration, size of firms and entry barriers). Pavitt's taxonomy uses these dimensions to identify four major clusters of sectors that display similar patterns of innovation: science-based, specialized suppliers, scale intensive, and supplier-dominated sectors.

Firms in science-based industries are typically large in size. They rely upon formal R\&D to source technology and innovate. Their knowledge base is complex and heavily dependent on scientific advances, so that the interactions between private firms and the science system is a major source of technological change. Specialized suppliers consist of small and medium size firms that are specialized in the production of advanced equipment and precision machineries. Firms in these industries innovate in products by relying mostly on internal sources of knowledge (such as R\&D coupled with engineering and design activities), and by interacting with advanced users of new technologies (i.e. firms in other sectors that purchase equipment and machineries and use them in their production process). Scale intensive sectors are among these advanced users. In the innovation process, they interact intensively with specialized suppliers by acquiring from them machinery, precision instruments, and specialized inputs as well as by integrating knowledge and capabilities coming from suppliers in their own engineering and production process. Firms in these sectors are large and try to exploit learning by doing mechanisms and scale economies linked to plant and market size. They innovate in both products and process. Finally, supplier-dominated industries constitute the least technologically advanced part of manufacturing. They generally do not develop their innovations internally in $\mathrm{R} \& \mathrm{D}$ labs and in production engineering departments. Rather they introduce cost-saving process innovations by acquiring and implementing advanced technologies, equipment and materials produced in other sectors. In short, their innovative 
trajectory is based upon embodied technological change undertaken by small and medium size enterprises (SMEs) with relatively low innovative capabilities.

In this paper, the main dimension of interest in the Pavitt taxonomy is the dominant strategy adopted by firms in different industries to generate new technologies and develop innovations. We call this dominant strategy R\&D orientation. We define $R \& D$ orientation as the extent to which firms in a given sector rely upon formal R\&D activities and investments in order to produce new products and processes, vis-à-vis other possible innovation strategies (e.g. acquisition of advanced capital machinery; acquisition of external knowledge; organizational and marketing innovation). ${ }^{1}$ Our focus upon R\&D orientation leads to the identification of two broad groups of sectors. One includes industries that are highly R\&Doriented, i.e. where R\&D is the main innovation strategy of firms - in Pavitts' terms sciencebased, scale-intensive and specialized suppliers. The other group includes sectors with low R\&D orientation, where firms employ a variety of innovation strategies different from formal R\&D activities (in Pavitt's terms supplier-dominated sectors). Given these sectoral differences in terms of $R \& D$ orientation, one may expect that firms in different industries respond differently to the incentives provided by $R \& D$ tax credits.

The literature on competition and innovation has, for a long time, focused on the relationships between degree of market concentration and the economic incentives to innovate. ${ }^{2}$ Early works found a positive relationship between concentration and R\&D (Horowitz, 1962; Hamberg, 1964; Scherer, 1967; Mansfield, 1968) and argued that presence of market power is a pre-requisite for innovation. An oligopolistic market structure is conducive to more innovation because high market power is associated with the availability of large internal financial resources to fund R\&D and also because it makes rivals' behavior more stable and predictable. This positive relationship between degree of concentration, $\mathrm{R} \& \mathrm{D}$ and innovation identifies the so called 'Schumpeterian effect'.

\footnotetext{
${ }^{1}$ It is important to emphasize that the concept of $R \& D$ orientation is distinct from the concept of $R \& D$ intensity. The former denotes the relative importance of $\mathrm{R} \& \mathrm{D}$ activities vis-à-vis other innovative strategies (e.g. alliances and/or collaboration with external actors), and it is mainly related to the sectoral patterns of technological change. The latter concept, instead, typically provides an indication of the total R\&D effort carried out by a firm and crucially depends also on firm's characteristics (such as the availability of internal vs. external financing resources).

${ }^{2}$ For an exhaustive review, see Cohen (2010).
} 
A second effect which predicts an opposite type of relationship is the "replacement effect" (Arrow, 1962). Here the economic incentives to engage in innovation are higher in competitive markets because firms' gains from innovation at the margin are higher. In fact for the 'replacement effect' the extent of displacement of existing rents by the innovation of the current leader is higher the higher the level of market concentration. Consistent with this, a more recently investigated mechanism is the so-called "escape competition effect". Aghion et al. (2005) have argued that the relationship between market structure and innovation depends on the type of rivalry. When firms innovate in a 'step-by-step' fashion (i.e. no leapfrogging is allowed) and rivals can compete 'neckand-neck' for customers, increasing competition leads to innovation because it increases the differential between pre and post innovation profits. Within this context, the relationship between concentration and innovation is negative as innovation is seen as a way to escape competition. When instead there is a leader firm and some laggards, increasing competition reduces the incentive of the laggards to innovate because post innovation rents remain too low due to competition with the leader.

It must be noted that the effect of concentration on innovation and $\mathrm{R} \& \mathrm{D}$ intensity can be mediated by other industry-level variables. Scherer (1967) found that when controlling for sector and technology classes fixed effects the explanatory power of market concentration alone on R\&D intensity declines. Lunn and Martin (1986) found that concentration affects R\&D intensity only in 'low opportunity' industries. Geroski (1990) found that not controlling for industry fixed effect the negative effect of concentration on innovation is reversed. Scott (1984) found that controlling for industry fixed effects market concentration coefficients are not significant. Comanor (1967) showed that the degree of product differentiation (as proxied by advertising intensity) conditions the relationship between concentration and R\&D intensity.

A complementary approach is the one on technological regimes and Schumpetrerian patterns of innovation. This approach does not focus only on incentives but also on the relationships between the technological features and the learning environment of an industry and the sectoral concentration 
of innovative activities. According to this view, a set of technological characteristics that are industry-specific - technological opportunities, cumulativeness, appropriability conditions, and the nature of the knowledge base - define a technological regime (Malerba and Orsenigo 1996; Breschi et al., 2000) and determine the Schumpeterian pattern of innovative activity: a Schumpeter Mark I pattern characterized by low concentration and high entry is related to high technological opportunities, low appropriability and low cumulativeness; and a Schumpeter Mark II pattern characterized by high concentration and low entry is related to high technological opportunities, high appropriability and high cumulativeness. Malerba and Orsenigo (1997) associate a Mark I pattern to supplier-dominated and specialized suppliers industries and a Mark II pattern to science-based and scale intensive industries, in this way linking their analysis to the Pavitt taxonomy described above.

Given these contributions on the relationship between market concentration and incentives to innovate and the diverse association between market concentration and innovation, we expect that differences in market concentration across industries will affect the response of firms in different industries to the incentives provided by $\mathrm{R} \& \mathrm{D}$ tax credits.

\subsection{Hypotheses development}

Consistent with the framework presented in the previous section, we examine how the sectorspecific R\&D orientation and concentration affect the input and output additionality effects of R\&D tax credits. To do this, we first have to examine how R\&D orientation and concentration are related to the propensity to receive a tax credit. In most countries that run R\&D fiscal incentive programs, in fact, the allocation of $\mathrm{R} \& \mathrm{D}$ tax credits is based on a selection mechanism (for a brief description of the characteristics and design of the $\mathrm{R} \& \mathrm{D}$ fiscal incentive program in Norway, France and Italy, see the Appendix). First, innovative firms assess whether they are eligible for the fiscal incentive based on the criteria specified by the program (e.g. according to the type of R\&D and innovation expenditures they have carried out). Second, those firms that are 
eligible for support decide whether they want to submit an application to the national authorities that manage the $\mathrm{R} \& \mathrm{D}$ tax credits programs. These authorities carry out an evaluation of all submitted applications. Hence, independently of the existence of not of a formal selection mechanism, only a subset of innovative firms are granted R\&D fiscal incentives. It is therefore important to take into account this selection process before turning to the analysis of additionality effects.

\subsection{1. $R \& D$ orientation and tax credits}

\section{Probability to receive a tax credit}

Sectoral $R \& D$ orientation affects the probability that a firm receives a $R \& D$ tax credits in two ways. The first is through a firm's propensity to apply to fiscal incentives schemes. In this respect, firms in both high and low orientation sectors apply to R\&D fiscal incentive schemes, though for different reasons. In high $\mathrm{R} \& \mathrm{D}$ oriented sectors, firms tend to be persistent innovators: doing $\mathrm{R} \& \mathrm{D}$ is their dominant strategy for developing new technologies. These firms typically engage in $\mathrm{R} \& \mathrm{D}$ projects that last years. Because of the nature of these projects they are more likely to invest in the related sunk costs; hence they are willing to apply for tax deductions in order to reduce the costs of their $R \& D$ projects and/or to scale them up. On the contrary, firms in lowtech and traditional manufacturing industries (such as supplier-dominated sectors in Pavitt's terms) pursue other types of innovative investment such as the purchase of new capital machineries, and organizational and marketing innovations and they seldom engage directly in R\&D. Also, low-tech and mature sectors are typically characterized by lower levels of technological and economic opportunities and less dynamic demand conditions than high-tech industries (Von Tunzelmann and Acha, 2005). As a consequence, firms in low R\&D orientation industries are on average more likely to experience financial constraints. Lack of finance to fund innovative activities may in particular be an important obstacle for SMEs. These reasons may lead to increase the propensity for firms in industries with low R\&D orientation to apply for tax credit 
schemes. Therefore, the responsiveness of firms to the tax credit in sectors with low R\&D orientation can also be interpreted as a signal that these firms apply to fiscal incentive programs primarily to achieve fiscal benefits and alleviate their financial constraints rather than to increase their $\mathrm{R} \& \mathrm{D}$ investments in a permanent way.

The second way in which $R \& D$ orientation affects the probability that a firm receives a $R \& D$ tax credit is through the company's $\mathrm{R} \& \mathrm{D}$ and managerial capabilities, which affect its ability to submit a good quality application (Takalo et al., 2013). In this respect firms in high R\&D orientation sectors have an advantage over firms in low R\&D orientation industries. As their innovative strategy revolves entirely around formalized $R \& D$ activity, firms in high $R \& D$ orientation sectors invest more time and financial resources in the R\&D activity including the process of application for tax credits. In addition, these firms are typically large organizations, and this means that their pool of human resources to employ in activities of searching, screening, and monitoring for available policy and tax schemes is larger than in the case of low R\&D oriented sectors. In short, while both types of firms have a positive propensity to apply for tax deductions, the more stable, formalized and strategic organization of innovative activity in high $\mathrm{R} \& \mathrm{D}$ oriented sectors makes firms in these industries more likely to submit good quality applications than firms in low R\&D oriented sectors. On the basis of this discussion we can hypothesize the following:

H1a: Firms' probability to receive a tax credit is greater in sectors with higher R\&D orientation.

\section{Input additionality}

Two contrasting dimensions are important for the analysis of how industry-specific factors may affect input additionality at the firm level: firms' resources and capabilities relevant for undertaking R\&D activities and firms' initial conditions and distance to the technological frontier. 
Firms in sectors with low R\&D orientation may be innovative but they typically invest relatively less in $\mathrm{R} \& \mathrm{D}$ (as compared to an average firm in sectors with high $\mathrm{R} \& \mathrm{D}$ orientation). This means that they have greater scope for learning and catching up in R\&D activities. Thus any given small increase in R\&D investments induced by a tax credit may lead to a relatively large effect on $R \& D$ intensity. Achieving an additionality effect will instead be more demanding and difficult for firms in high $\mathrm{R} \& \mathrm{D}$ oriented sectors, due to their relatively high level of $\mathrm{R} \& \mathrm{D}$ expenditures.

However, in sectors where $\mathrm{R} \& \mathrm{D}$ is the main innovation strategy (e.g. science-based and specialized suppliers), firms may find it easier, on average, to increase their R\&D investments by building upon and extending previous $\mathrm{R} \& \mathrm{D}$ projects, since they have previously developed a specific R\&D strategy and sustained the related initial fixed costs. Success-breeds-success and cumulativeness mechanisms would also lead R\&D active companies to continue to invest in $\mathrm{R} \& \mathrm{D}$ in the future, and particularly so in the presence of fiscal incentives. In addition to this, technological opportunities are typically higher in industries with high R\&D orientation, and this gives innovative companies a further incentive to increase their $\mathrm{R} \& \mathrm{D}$ expenditures as a response to a fiscal stimulus. We thus expect the following:

H1b: The input additionality effect is positive in both sectors with high and low RED orientation. However, the effect is greater for firms in sectors with higher R\&D orientation.

\section{Output additionality}

Two contrasting effects must be considered when looking at output additionality. On the one hand, a firm's starting conditions and distance to the technological frontier matter. A given amount of tax credit may lead to a relatively stronger increase in innovation output if a firm starts from a lower innovation output level. Hence, any small increase in product innovation output represents a relatively stronger output additionality effect for firms in low R\&D orientation 
industries. This sort of reversion to mean effect is therefore explained by differentials in the initial conditions (in terms of technological output) that firms face in different industries.

On the other hand, there are reasons to expect output additionality effects to be stronger in sectors with high R\&D orientation. Firms in these industries are typically better at transforming innovative inputs into output because they have on average higher technological capabilities (due to previously accumulated technological knowledge and R\&D capabilities). Further, firms in high $\mathrm{R} \& \mathrm{D}$ orientation sectors tend to be diversified and to enjoy economies of scope (see Henderson and Cockburn, 1996). Thus, firms active in industries with high R\&D orientation may be more likely to transform the additional R\&D investment induced by a tax credit into new products. We thus formulate the following hypothesis:

H1c: The output additionality effect is positive in both sectors with high and low R $\sigma D$ orientation. However, the effect is greater for firms in sectors with higher R\&D orientation.

\subsubsection{Market concentration and tax credits}

\section{Probability to receive a tax credit}

The effect of market structure on the probability that a firm receives a $R \& D$ tax credits works through the Schumpeterian effect and the escape-competition effect described above. If the Schumpeterian effect prevails, oligopolistic innovators in highly concentrated sectors have a greater incentive to apply for tax credits because they can more easily reap innovation rents and hence sustain their market lead. This is more likely to be observed in Schumpeter Mark II industries where appropriability is high. If instead the escape-competition effect prevails, firms must compete 'neck-to-neck' in the same market: they may find it attractive to apply to R\&D fiscal programs because they consider innovation essential to improve their competitive position. Which one of the two effects prevails is an empirical matter. We thus formulate our hypothesis as follows: 
H2a: If a Schumpeterian effect prevails, firms' probability to receive a tax credit is greater in sectors with higher concentration.

\section{Input additionality}

The extent of input additionality depends on how market structure affects firms' propensity to invest in $\mathrm{R} \& \mathrm{D}$. In more concentrated industries, there is less aggressive/non cooperative interaction, while in more competitive industries there is no interdependent decision making (Scott, 2009). Low rivalry and reduced uncertainty would increase the propensity of incumbent firms to spend in R\&D. In this case, a Schumpeterian effect prevails. On the other hand, in a more competitive environment populated by many competitors, excessive rivalry increases uncertainty and reduces incentives to invest in R\&D. If an escape competition effect prevails, the incremental profits that firms may gain by investing in $\mathrm{R} \& \mathrm{D}$ activities are higher than in a concentrated market. Therefore in less concentrated markets the intensity of competition would lead more capable firms to invest more in R\&D (Lee, 2011). Our hypothesis is as follows:

H2b: If a Schumpeterian effect prevails, the input additionality effect is greater in sectors with higher concentration.

\section{Output additionality}

Finally, to analyze the relationship between output additionality and market structure, we must consider the possible outcomes from the availability of R\&D tax credits. First, innovative output grows when the efficient production scale of a firm tends to grow more rapidly than demand (Levin, 1978). This historically happened in highly concentrated sectors such as electric power and generation (Hughes, 1971), chemicals (Levin, 1977), steel, cement, brewing, refrigerators and batteries (Scherer et al., 1975). More in general, we might expect this mechanism to work any time innovation affects long-lived capital and/or induce costly adjustments on the demand side. 
Second, the possibility to increase innovative output depends on the presence of cumulativeness conditions as well as on persistence (i.e. success-breeds-success) in innovative activities (Malerba and Orsenigo, 1996; Breschi et al., 2000). Both effects are on average stronger in more concentrated sectors such as Schumpeter II industries than in less concentrated ones, (see Phillips' (1971) analysis of aircraft industry, and Malerba and Orsenigo (1997) for a wide variety of industries). When these mechanisms are at work, output additionality will arguably be skewed and mainly obtained through R\&D spending performed by few oligopolistic innovators rather than spread uniformly across many small R\&D innovators.

The role of firm size may work in this direction too. The innovative output increases with the size of the innovative firm - which is typically higher in concentrated sectors - because the innovator has a larger volume of sales over which to spread the fixed costs of innovation (particularly process innovation) (Cohen and Klepper, 1996). For all these reasons it is reasonable to expect that any given increase in $\mathrm{R} \& \mathrm{D}$ induced by a tax credit will lead to a stronger output additionality effect in a highly concentrated market than in a less concentrated industry. We thus formulate the following hypothesis:

H2c: The output additionality effect is positive in both high and low concentration sectors. However, the effect is greater in sectors with higher concentration.

\section{Model, data and methods}

\subsection{Model specification}

To test our hypotheses we have developed an empirical model which consists of the following three equations: 


$$
\operatorname{Pr}\left\{\mathrm{TC}_{\mathrm{ij}}\right\}=a+\beta \mathrm{X}_{\mathrm{ij}}+\gamma \mathrm{RD}_{\mathrm{j}}+\delta \mathrm{C}_{\mathrm{j}}+\varepsilon_{\mathrm{ij}}
$$

$$
\mathrm{RDI}_{\mathrm{ij}}=\mu+\eta \mathrm{TC}_{\mathrm{ij}}+\theta \mathrm{W}_{\mathrm{ij}}+\varkappa \mathrm{RD}_{\mathrm{j}}+\lambda \mathrm{C}_{\mathrm{j}}+\zeta_{\mathrm{ij}}
$$

$$
\mathrm{IO}_{\mathrm{ij}}=v+\psi \mathrm{RDI}_{\mathrm{ij}}^{\mathrm{C}}+\pi \Delta \mathrm{RDI}_{\mathrm{ij}}+\sigma \mathrm{Z}_{\mathrm{ij}}+\varphi \mathrm{RD}_{\mathrm{j}}+\omega \mathrm{C}_{\mathrm{j}}+\xi_{\mathrm{ij}}
$$

Equation 1 estimates the probability that a firm receives a $\mathrm{R} \& \mathrm{D}$ tax credit $\left(\mathrm{TC}_{\mathrm{ij}}\right)$. This probability is a function of a vector of firm-level characteristics $\left(\mathrm{X}_{\mathrm{ij}}\right)$, plus two industry-level factors representing the $\mathrm{R} \& \mathrm{D}$ orientation of industry $j\left(\mathrm{RD}_{\mathrm{i}}\right)$, and its concentration level $\left(\mathrm{C}_{\mathrm{j}}\right)$. Equation 2 estimates the R\&D intensity of firm $i$ as a function of the tax credits it has received, a vector of firm-level characteristics $\left(\mathrm{W}_{\mathrm{ij}}\right)$, as well as the industry's $\mathrm{R} \& \mathrm{D}$ orientation and concentration level. The parameter $\eta$ in this equation measures the input additionality effects. Finally, equation 3 estimates the innovation output of firm $i\left(\mathrm{IO}_{\mathrm{ij}}\right)$ as a function of its $\mathrm{R} \& \mathrm{D}$ intensity, a vector of firm-level characteristics $\left(Z_{i i}\right)$, and the industry's $R \& D$ orientation and concentration level. The parameter $\pi$ in this equation does therefore measure the output additionality effects. ${ }^{3}$

\subsection{Data and indicators}

We use a panel of firm-level data for all manufacturing industries originated from the innovation surveys for three countries: Norway, France and Italy. For Norway and France, the data source are the three waves of the Community Innovation Survey (CIS) referring to the periods 20022004, 2004-2006 and 2006-2008, respectively. For Italy, the data source is the innovation survey called Unicredit/Efige, whose questionnaire is largely consistent with the CIS questionnaire. ${ }^{4}$

\footnotetext{
${ }^{3}$ It is important to stress once again that the two industry-level variables in equations $1-3$ measuring the R\&D orientation of industry $j\left(\mathrm{RD}_{\mathrm{j}}\right)$ and its concentration level $\left(\mathrm{C}_{\mathrm{j}}\right)$ capture two independent dimensions. From a theoretical viewpoint, these variables represent quite distinct concepts (industry specific innovation trajectories vs. market concentration) that are analyzed in different branches of the literature. From an empirical point of view, the correlation between these variables in our datasets is very low (the correlation coefficients among these variables range in nearly all cases between 0 and 0.15 ). It is therefore appropriate to include both these dimensions in our empirical model specification.

4 The three waves of the Italian survey refer to the periods 2001-2003, 2004-2006 and 2007-2009.
} 
These firm-level data is combined with information on R\&D tax credits available from tax office authorities in these countries.

These three countries have in place R\&D tax credit programs with different designs. In Norway and Italy, tax credits have a volume-based design, while France adopted an incremental-based scheme until 2008 (when our investigation period ends). In addition, in Norway the scheme previews a selection made by the tax authorities, in France eligibility of the R\&D expenditures is checked ex-ante by tax authorities, while in Italy a review of eligibility occurs ex-post through ordinary controls of the accuracy of tax declarations (for more details see the Appendix).

\section{Dependent variables}

- TC: R\&D tax credit dummy (1 if firm is granted a R\&D fiscal deduction in the period, 0 otherwise). This is the dependent variable in equation 1.

- RD_INTENSITY: R\&D expenditures as a percentage of total turnover (0-100 scale). This is the dependent variable in equation 2.

- TURN_NEW: Share of turnover from new or improved products (0-100 scale). This is the dependent variable in equation $3 .{ }^{5}{ }^{6}$

\footnotetext{
${ }^{5}$ In the surveys, the values for this variable are self-reported by the respondents. As a result, the variable tends to be distributed unevenly and concentrated instead around a limited number of discrete values (e.g. 0, 10, 20, 30, ..., 100). For this reason, we have transformed this variable into a categorical indicator taking integer values from 0 to 10 (as done in Czarntizki et al., 2011), and used an ordered probit model for the estimation of equation 3. Thanks to a reviewer for suggesting this possibility.

${ }^{6}$ It is important to note that the three dependent variables used in this study focus on firms' R\&D investments and the related product innovation output. These variables are typically used in this literature to measure manufacturing firms' innovative efforts and results. It would however be interesting, in future extension of this line of research, to investigate the corresponding patterns for firms in the service sectors, which often use different innovative strategies and commercialize different types of innovation than enterprises in manufacturing sectors.
} 


\section{Firm-level control variables}

- SIZE: Number of employees (log).

- H_FINANCE_INT: This is a categorical variable (0-3 scale) capturing the extent to which firms consider the lack of internal funding an important factor hampering their innovative activities.

- H_FINANCE_EXT: a categorical variable (0-3 scale) measuring the extent to which firms consider the lack of external funding an important factor hampering their innovative activities.

- H_PERSONNEL: a categorical variable (0-3 scale) indicating the extent to which firms consider the lack of qualified personnel an important factor hampering their innovative activities.

The degree to which financial and personnel resources are perceived to hamper firms' innovation activity provides information on the need to leverage investment in financial and personnel resources. $^{7}$ The Italian survey does not contain analogous questions on hampering factors. We have therefore defined these three variables in a slightly different manner in the Italian dataset. Rather than the self-reported perception of the managers, they reflect the effective financial and personnel resources of firms. H_FINANCE_INT: firm's cash flow as a share of total assets. H_FINANCE_EXT: the degree of firm's leverage / availability of external financial resources (debts/equity). H_PERSONNEL: share of employees with higher education. We have transformed these three control variables on a 0-3 categorical scale in order to make them consistent with the corresponding variables in the Norwegian and French datasets. In section 4,

\footnotetext{
${ }^{7}$ Some studies have shown that the more firms are highly innovative and experienced the more they are likely to report barriers as important (Mohnen and Rosa, 2002). D'Este et al. (2012) point out instead that financial barriers have also a deterrence effect on firms' innovation.
} 
we will discuss the potential drawbacks (and advantages) of using a slightly different definition for these control variables in the Italian dataset.

- COOP: Innovation cooperation dummy (1 if the firm has had cooperation, 0 otherwise).

- EXPORT: Export dummy (1 if the company was active in international markets, 0 otherwise).

- GROUP: Group affiliation (1 if the firm was part of a group, 0 otherwise).

\section{Industry-level control variables}

The $\mathrm{R} \& \mathrm{D}$ orientation variable $\left(\mathrm{RD}_{j}\right)$ included in equations 1 to 3 is measured through four dummy variables representing the four industry groups identified by Pavitt's (1984) taxonomy:

- SS (specialized suppliers)

- $\quad$ SB (science-based)

- SI (scale intensive)

- SD (supplier-dominated)

We have made a correspondence table between NACE 2-digit industries and Pavitt sectors based on previous empirical analyses of Pavitt's taxonomy (Castellacci, 2008). This correspondence table is the same for the three countries.

Regarding the concentration level variable $\left(\mathrm{C}_{j}\right)$, we measure it by means of two dummy indicators:

- LC (low-concentration sectors, or Schumpeter Mark I, SMI) 
- HC (high-concentration sectors, or Schumpeter Mark II, SMII)

These dummies have been constructed as follows. We have used data on the Herfindahl concentration index (HHI) for each NACE 2-digit sector, each year, and each country. ${ }^{8}$ We have classified each NACE 2-digit industry as high-concentration (HC) if its $\mathrm{HHI}$ is above the median (for a given year and country), and as low-concentration (LC) if its HHI is below the median. We have repeated this classification exercise separately for each year and each country. Finally, we have made a correspondence table between NACE 2-digit industries and high- low- sectors (SMI and SMII). This correspondence table is slightly different across the three countries (i.e. a given NACE sector may be more or less concentrated in different countries), but it is largely the same over time (i.e. a highly concentrated industry in the first survey period is in most cases classified as highly concentrated also in the subsequent two periods).

Table 1 presents descriptive statistics for the firm-level indicators for Norway, France and Italy, respectively. Table 2 reports the correlation coefficients for these variables in each national dataset.

\section{$<$ Table 1 and table 2 here $>$}

\subsection{Estimation method}

We estimate equations 1 to 3 through a three-step procedure. This follows the method used by Czarnitzki and Hussinger (2004) in their analysis of the input and output additionality effects of R\&D subsidies on German firms. ${ }^{9}$ This three-step procedure has been applied separately to each national panel dataset.

The first step estimates the probability that a company receives a $\mathrm{R} \& \mathrm{D}$ tax credit (equation 1 ). We estimate this selection equation on the panel dataset (three survey periods) for each country

\footnotetext{
${ }^{8}$ The source of HHI data is the Micro-Dyn database, available at: http://www.micro-dyn.eu.

${ }^{9}$ Cerulli and Poti (2012: 31) also adopted a similar procedure in their analysis of input and output additionality of the Italian R\&D policy scheme FAR. See also Czarnitzki and Delanote (2014) for a recent overview of this type of modeling approach.
} 
by means of a random effects probit model. The second step employs a propensity score matching approach to estimate input additionality effects. We use a nearest-neighbor matching algorithm (using STATA commands "teffects" and "psmatch2"). For each country, we have carried out the matching exercise separately for each year and for each of the six sectoral groups (the four Pavitt's groups as well as the two groups denoting high- and low-concentration industries). The results of this matching exercise is an estimate of the input additionality of $R \& D$ tax credits - so-called average treatment effect on the treated (ATET) - for each country, year and sectoral group.

The third step estimates the output additionality effects (equation 3) on the pooled dataset (three survey periods) for each country by means of a panel random effects ordered probit model with bootstrapped standard errors. We use an ordered probit model to account for the fact that the dependent variable in this equation, TURN_NEW, is defined as a categorical variable on an ordinal scale). ${ }^{10}$ This equation includes among the regressors two variables obtained by splitting the R\&D intensity variable predicted from step 2 into two distinct terms. The additional R\&D intensity generated by a tax credit, $\Delta \mathrm{RDI}_{\mathrm{i},}$, is represented by the treatment effect on the treated (TET) for each firm obtained in step 2 of the analysis. The counterfactual R\&D intensity (that each company would have done in the absence of a tax credit), $\operatorname{RDI}^{\mathrm{C}} \mathrm{i}$, is simply obtained as the difference between $\mathrm{RDI}_{\mathrm{ij}}$ and $\Delta \mathrm{RDI}_{\mathrm{ij}}$ for each firm in the sample. ${ }^{11}$

This third step of the estimation method differs from Czarnitzki and Hussinger (2004) and Cerulli and Poti (2012) in one important aspect. Since we are interested in analyzing crossindustry differences in additionality effects, we employ interaction variables to study the extent to which output additionality differs among sectors that have different $\mathrm{R} \& \mathrm{D}$ orientation and concentration levels. These interaction variables are constructed as the product of each sectoral

\footnotetext{
${ }^{10}$ In addition to the ordered probit model, we have also estimated the model using the continuous version of the TURN_NEW dependent variable by means of a random effects linear model and a random effects tobit model. Results hold across the different estimations.

${ }^{11}$ For firms that do not receive a tax credit, the term $\Delta \mathrm{RDI}_{i j}$ takes a value of 0 , while the term $\mathrm{RDI}_{i j}$ takes the same value as the firm's R\&D intensity $\mathrm{RDI}_{i j}$.
} 
group dummy and the input additionality term TET. The interaction variables that we use in equation 3 are therefore four for the Pavitt groups (TET $\bullet$ SS; TET $\bullet$ SB; TET $\bullet$ SI; TET $\bullet S D$ ) and two for the high- and low-concentration sectoral groups (TET • HC; TET • LC).

In order to assess the robustness of the results, we have carried out this three-step procedure for four different specifications. The first is the baseline specification noted above and run on the whole sample of observations. The second specification includes two additional regressors in the matching analysis (equation 2): a lagged R\&D dummy (indicating whether firms were engaged in $\mathrm{R} \& \mathrm{D}$ in the previous survey period), and the lagged value of the RD_INTENSITY variable. This specification improves the matching quality by restricting the control and treatment groups only to firms for which we have information on their past engagement in $\mathrm{R} \& \mathrm{D}$ investments. The drawback of this strategy, however, is that we lose a sizeable number of observations (due to the unbalanced nature of our panels). The third specification follows the identification strategy used by Czarnitzki et al. (2011), and runs the baseline model specification only on the sub-sample of innovative firms. ${ }^{12}$ Finally, the fourth specification considers the possible complementarities between $R \& D$ tax credits and R\&D subsidies, and provides a robustness check of the results by excluding those firms that received both tax credits and direct grants (as done in Czarntizki et al., 2011).

\section{Results}

Tables 3 to 5 report the results of the estimations of equations 1,2 and 3 for the first two econometric specifications (baseline full sample; with lagged R\&D, smaller sample), whereas table

\footnotetext{
${ }^{12}$ As done by Czarnitzki et al. (2011), we define 'innovative firms' as those that have introduced at least one product innovation in the period.
} 
6 presents a summary of the results for all the four specifications, and a comparison of the tests of our six hypotheses across countries and econometric specifications. ${ }^{13}$

\subsection{The probability to receive a $R \& D$ tax credit}

Table 3a presents the estimation results for equation 1 for the baseline specification (full sample), and Table $3 \mathrm{~b}$ for the second specification (including lagged $\mathrm{R} \& \mathrm{D}$, and run on a smaller sample). Looking first at the results for the dummies for Pavitt's sectoral groups, for all the three countries the estimated marginal effects are positive and significantly higher for the SB and SS dummies than those for the reference group (SD). The magnitude of these marginal effects is quite strong for Norway and France, and weaker for the Italian case. Table 6 (reported at the end of this section) indicates that these results are also robust across model specifications, providing clear support for hypothesis $\mathrm{H} 1 \mathrm{a}$, that the probability to receive a $\mathrm{R} \& \mathrm{D}$ tax credit is on average greater in sectors with higher R\&D orientation.

The dummy variable LC tests $\mathrm{H} 2 \mathrm{a}$ on the role of market concentration. In Table 3a, the LC (lowconcentration) variable is negative and significant for Norway and France, and not significant for Italy. For specification 2 (Table 3b) and the rest of econometric specifications (see the summary in Table 6), the variable is mostly not significant for Norway and Italy, while it has a stable and significant negative estimated coefficient for France. Hence, our evidence supports the hypothesis that a firm's probability to receive a tax credit is higher in sectors with stronger concentration only for the case of France.

The remaining coefficient estimates reported in the tables refer to our set of controls: size, internal and external finance, human capital, presence in international markets and group affiliation. The estimated coefficient for SIZE indicates that larger firms have on average a greater ability (propensity) to receive tax credits. Regarding the three hampering factor control variables (H_FINANCE_INT, H_FINANCE_EXT, H_PERSONNEL), their estimated

\footnotetext{
${ }^{13}$ The results for the third and fourth specifications, along with some other robustness exercises, are not reported in the paper to save space, and are available upon request.
} 
coefficients have all the expected positive sign in the regressions. It is interesting to note here that, despite the fact that these variables have slightly different definitions in Italy vis-à-vis Norway and France, the results for the three countries are consistent with each other and confirm the importance of firms' financial and human resources to determine their ability to benefit from R\&D tax credits schemes. ${ }^{14}$ The EXPORT dummy variable is positive and significant for all three countries. Finally, the GROUP dummy indicator that we include to control for group affiliation is not significant for Norway and Italy, and it is negative and significant for France, indicating that French firms that are not affiliated to business groups have a higher propensity to benefit from tax credit schemes than group-affiliated companies.

\section{$<$ Tables $3 a$ and $3 b$ here $>$}

\subsection{The input additionality effects}

Tables $4 \mathrm{a}$ and $4 \mathrm{~b}$ report the results of propensity score matching estimations for the first two model specifications respectively, separately for each country, year and sectoral group. Since our $\mathrm{R} \& \mathrm{D}$ variable is defined as $\mathrm{R} \& \mathrm{D}$ intensity ( $R \& D$ as a percentage of turnover), the ATT parameters reported in these tables measure the additional $\mathrm{R} \& \mathrm{D}$ intensity of the firms induced by tax credits - for each country, year and sectoral group. Our findings are the following.

First, for all countries and years, except for Italy in the period 2004-2006, input additionality is positive. Second, comparing the results among the four Pavitt sectoral groups, we note that input additionality effects are on average stronger in SB and SS. These sectoral patterns are mostly consistent across countries, and hold across the four econometric specifications (see Table 6). ${ }^{15}$

\footnotetext{
${ }^{14}$ These results suggest that managers have a good perception of how their financial and personnel resources differ from the other firms' in the same and related markets.

${ }^{15}$ There are two notable exceptions to this general pattern. The first is that for Norway, and only for the year 2008, it is the SD group that has the highest input additionality. The second exception is that input additionality always turns out to be negative for Italy in the period 2004-2006. This means that, in this period, the average R\&D intensity of the treated firms is lower than the one of the untreated firms, (see Panel C1 of Table 7 in the Appendix), although the relative drop of the average R\&D intensity experienced during the period 2004-2006 has been steeper for the
} 
These results are in line with $\mathrm{H} 1 \mathrm{~b}$ : input additionality is greater in sectors with higher R\&D orientation, such as science-based and specialized suppliers.

Third, comparing the ATT coefficients for low-concentration (LC) and high-concentration (HC) industries, we find that input additionality effects are stronger in sectors with higher concentration. The result is consistent across the years and the four model specifications for France, whereas it is less robust for Norway and Italy (it holds for specifications 1 and 4 for Norway, and for specifications 1, 3 and 4 for Italy). All in all, however, this evidence is in line with $\mathrm{H} 2 \mathrm{~b}$. The results on cross-industry variations in input additionality are on the whole consistent across the three countries considered in this paper.

Although the analysis of cross-country differences in input additionality effects is not the focal point of this paper, it is interesting to provide a more thorough analysis of cross-country differences between Norway, Italy and France. The Appendix presents a brief description of the characteristics and design of $\mathrm{R} \& \mathrm{D}$ tax credits programs in these countries, and the results of an additional exercise based on a difference-in-difference-in-difference (DDD) econometric model (Angrist and Pischke, 2008). The additional results presented in the Appendix are in line with the results reported in tables $4 \mathrm{a}$ and $4 \mathrm{~b}$. They show that input additionality effects have been significantly stronger in Norway and Italy than in France. This pattern seems to hold for all sectoral groups.

What can explain these cross-country differences? One possible interpretation of this pattern is that countries with a volume-based design - such as Norway and Italy - tend to have stronger input additionality effects than countries that adopt an incremental-based scheme like France (at least until the year 2008, when our investigation period ends). A volume-based scheme applies to the whole stock of qualified R\&D expenditures carried out by a firm, and it is better suited to provide support to large $\mathrm{R} \& \mathrm{D}$ intensive companies. By contrast, an incremental scheme only

latter group. This drop of the average R\&D intensity in 2004-2006 (a period of relative economic expansion in Italy) is in line with the Schumpeterian view of business cycles and growth that predicts a countercyclical fluctuation of firm's R\&D investments, driven by the different opportunity costs of long-term innovative investments with respect to short-term capital investments, which is lower in recessions than in booms (Aghion et al. 2012). This may explain why we observe in our results a stronger crowding-out effect of R\&D tax credits during economic booms (as in 2004-2006) rather than during economic downturns. 
applies to the additional amount of R\&D that the company does above a given base amount, and it may therefore be more appealing for smaller companies, which may find it easier to increase this low initial R\&D level in order to qualify for the fiscal benefits (Castellacci and Lie, 2015). In our sample, France is the country that has the largest average firm size. It is therefore possible to argue that large firms in France have not experienced substantial input additionality effects for the reason noted above, namely that the incremental fiscal incentives scheme that was in place in the country until 2008 did not provide them with a strong enough incentive to increase their $\mathrm{R} \& \mathrm{D}$ expenditures. This argument may possibly explain why the estimated input additionality in our study turns out to be weaker for the country with an incremental scheme. It is however important to take this interpretation with due caution, since the results of this paper are based on the comparison of three countries only, and it would be necessary to examine empirical evidence for other countries before drawing any robust conclusion on the effects of R\&D policy design on input additionality.

\section{$<$ Tables $4 \mathrm{a}$ and $4 \mathrm{~b}$ here $>$}

\subsection{The output additionality effects}

Tables $5 \mathrm{a}$ and $5 \mathrm{~b}$ report the estimation results for equation 3 for the first two model specification respectively. The R\&D counterfactual variable (RD_COUNTER) is positive and significant in most of the regressions, in line with analogous previous exercises carried out by Czarnitzki and Hussinger (2004) and Cerulli and Poti (2012). The other term of interest is the additional R\&D intensity generated by a tax credit (i.e. the treatment effect on the treated (TET) estimated in equation 2). We interact this TET variable with the six sectoral group dummies, in order to test the extent to which output additionality differs among sectors that have different $R \& D$ orientation and concentration levels. Specifically, Table 5 presents two different specifications of this piecewise linear model: one with interaction variables for the Pavitt groups (TET • SS; TET • 
$\mathrm{SB}$; TET $\bullet$ SI; TET $\bullet$ SD) and one with interactions for the high- and low-concentration sectoral groups $(\mathrm{TET} \bullet \mathrm{LC}$; TET $\bullet \mathrm{HC})$.

Before commenting upon cross-industry differences, it is important to point out the general pattern emerging from the estimation of equation 3. For all countries and most model specifications, the TET interaction variables always turn out to have a positive and significant estimated coefficient. This means that our analysis provides clear and robust evidence on the existence of output additionality for Norway, France and Italy. In these countries, R\&D tax credit programs have both led to an increase in $\mathrm{R} \& \mathrm{D}$ spending and an increase in firms' turnover from new products. This result is important because, as noted in Section 2, most of the literature on R\&D policy evaluation has so far focused on the analysis of input additionality and typically neglected the study of output additionality effects. Our results on positive output additionality are in line with the recent study of Czarnitzki et al. (2011), focused on the new product performance of Canadian companies, and the one of Cappelen et al. (2012), which studied the innovation and patenting performance of Norwegian firms as a response to the Norwegian tax credit scheme.

Shifting now the focus to the analysis of cross-industry variations in output additionality, Tables $5 \mathrm{a}$ and $5 \mathrm{~b}$ (columns 1, 3 and 5) show that the estimated coefficients for the four Pavitt interaction variables differ somewhat among the three countries. In Norway, it is the scale-intensive industry group that has the highest estimated output additionality in all four model specifications, and cross-industry differences are statistically significant in the first specification. In Italy, the group with strongest output additionality effects in all model specifications is SS (although the differences among the four Pavitt groups are jointly not statistically significant). The results for Norway and Italy overall provide support for $\mathrm{H} 1 \mathrm{c}$, according to which the output additionality effect is positive for both firms with high and low R\&D orientation, but greater for firms in sectors with higher R\&D orientation (such as SS and SI). By contrast, the results for France indicate that SS and SD firms are those with the highest estimated output additionality effects. 
The large output additionality impact for SD industries in France is not in line with our hypothesis H1c.

Regarding the interaction variables testing differences between low- and high-concentration industries, the results of these tests lead to non-robust and inconclusive results. In Norway, the estimated output additionality coefficient for LC sectors is higher than for HC industries, and these differences are significant in the first and fourth specifications. For Italy, results also indicate stronger output additionality for LC than for $\mathrm{HC}$ in specifications 1, 3 and 4 (although these sectoral differences are not statistically significant). For France, we find significantly stronger output additionality effects for LC only in specification 1, whereas the results specifications 2, 3 and 4 are weakly significant and report a higher coefficient for $\mathrm{HC}$ sectors. On the basis of these results, it is important to be cautious and not draw any strong conclusion on the validity of our hypothesis H2c, and particularly for France.

All in all, these results indicate that output additionality effects do not only vary among sectors, but do also differ substantially between the three countries examined in this paper. In Norway, the highest estimated output additionality is for scale-intensive industry group and for lowconcentration industries. In Italy, the groups with strongest output additionality effects are specialized suppliers and low-concentration industries. In France, output additionality is instead stronger for specialized suppliers and supplier-dominated industries. It is indeed hard to put forward an explanation for such cross-country differences based on the results for three countries only. One possibility would be that output additionality chiefly depends on the type of design of the R\&D policy (as discussed in section 4.2 above). Another possibility would be that additionality effects turn out to be stronger in sectors of national specializations, where an advanced home market magnifies the effects of R\&D policy schemes. However, these arguments are not tested explicitly in our paper, and they call for future research examining cross-country differences in R\&D policy effects for a larger number of economies. 


\section{$<$ Tables $5 \mathrm{a}$ and $5 \mathrm{~b}$ here $>$}

\subsection{Summary of main findings}

After having commented above on the results of each of the six hypotheses separately, it is important to present a summary view of our results and their joint relevance (see Table 6).

First, the results of our three hypotheses on the role of the R\&D orientation (H1a, H1b, H1c) indicate a clear and robust pattern. Firms in sectors with higher R\&D orientation, and specifically SB and SS, have on average higher propensity to receive tax credits, as well as stronger input additionality and stronger output additionality (the latter result only holds for Norway and Italy). It is important to point out that the lack of significant support for cross-industry differences in output additionality for France does not imply that these sectoral differences are not important. Since we find clear evidence of output additionality in the whole sample (all TET variables are positive and significant, regardless of cross-industry differences), our results imply that every Euro of tax credit leads on average to a higher increase in R\&D spending in SB and SS sectors, and this in turn implies that - if the output additionality elasticity is not significantly different across industries (as in France) - the increase in new product turnover will on average be stronger in these high R\&D orientation industries than in other sectors. ${ }^{16}$

Second, the results of our three hypotheses on the role of industry concentration $(\mathrm{H} 2 \mathrm{a}, \mathrm{H} 2 \mathrm{~b}$, H2c) indicate a clear and robust pattern only in the case of France. French firms in more concentrated markets have on average a higher propensity to receive tax credits and stronger input additionality effects. Since we do not find significant and robust support for cross-industry differences in output additionality for France, this means that - for the same reason noted above - highly concentrated sectors are also those where we observe a higher average increase in innovation output.

\footnotetext{
16 In other words, referring to the notation used in equation 3, this means that the estimated output elasticity parameter $\pi$ is not significantly different across sectors, but the corresponding regressor $\Delta \mathrm{RDI}_{i j}$ (which in turn is estimated in equation 2) is higher for R\&D intensive industries. This implies that the innovation output $\mathrm{IO}_{i j}$ does on average increase faster in more $\mathrm{R} \& \mathrm{D}$ intensive sectors as a result of the fiscal incentives policy.
} 


\section{$<$ Table 6 here $>$}

\section{Conclusions and policy implications}

This paper has argued that the additionality effects of $R \& D$ tax credits systematically vary across sectors, depending on industries' degree of R\&D orientation and market concentration. We have developed a set of hypotheses on how these two sector-specific dimensions affect firms' probability to receive $\mathrm{R} \& \mathrm{D}$ tax credits, as well as the consequent input and output additionality effects. These hypotheses have then been tested on a large panel of firms in Norway, Italy, and France. The results can be summarized by the following two general findings.

First, regarding the effects of industry concentration levels, our econometric results are only significant and robust for the case of France. For this country, we find that firms in more concentrated markets have on average higher propensity to receive tax credits and stronger input additionality effects. Output additionality effects are not significantly different across sectors. Taken together, these results imply that highly concentrated sectors are also those where we observe a higher average increase in innovation output. This is an interesting finding and it may potentially have relevant policy implications. However, we do not find statistically significant support for this pattern in Norway and Italy. It is therefore important that, before drawing policy implications based on this result, future research will further investigate the relationships between industry concentration and R\&D policy additionality by considering several other countries that have fiscal incentives programs.

The second finding refers to the role of the industry-specific R\&D orientation, i.e. the extent to which firms in each sector have $\mathrm{R} \& \mathrm{D}$ as the main strategy to develop new products and technologies. Our econometric results clearly indicate that firms in industries with a higher R\&D orientation - and in particular science-based and specialized suppliers - have on average stronger 
(input) additionality effects than companies in sectors where formal $\mathrm{R} \& \mathrm{D}$ is not the main innovation strategy, such as supplier-dominated sectors.

Regarding output additionality, we find positive additionality effects in the whole sample of firms for all the three countries. This is an important finding, given that much of the previous literature on R\&D tax credits - with the notable exceptions of the recent works of Czarnitzki et al. (2011) and Cappelen et al. (2012) - has typically focused on input additionality and mostly neglected the analysis of output additionality effects.

In relation to cross-industry differences in output additionality, we also find significant support indicating that these effects are stronger for sectors with higher $\mathrm{R} \& \mathrm{D}$ orientation for the case of Norway and Italy. We do not find significant support for cross-industry differences in France, though. As noted at the end of the previous section, our results for France taken together imply that any given amount of fiscal incentive leads to a higher increase in $R \& D$ investments in science-based and specialized supplier sectors: in the absence of sectoral differences in the output additionality elasticity, this leads to a greater average increase in new product turnover in these R\&D intensive industries.

Our findings on cross-sectoral differences in input and output additionality are relevant for innovation policy. The fact that $\mathrm{R} \& \mathrm{D}$ fiscal incentives lead to stronger additionality effects in $\mathrm{R} \& \mathrm{D}$ intensive sectors means that, although these policy schemes are typically horizontally defined (i.e. providing firms in different industries with the same set of incentives), their effects vary systematically across sectors, being stronger for companies in more R\&D oriented industries than for firms in sectors with lower R\&D orientation. This means that, if the policy objective is to increase the overall $R \& D$ intensity of the economy, $R \& D$ fiscal incentives programs may be considered to be an effective policy instrument - since they have in general relatively low administrative costs and relatively stronger impacts on R\&D intensive firms and sectors. However, the findings of this paper - that horizontally defined schemes may have non-horizontal 
(i.e. industry-specific) effects - only refer to the three countries considered in this work, and it calls for further research for other countries.

\section{Acknowledgments}

This paper is produced as part of the project " $R \& D$ Policy by Sector: A Cross-country Investigation". Financial support from the Norwegian Research Council (FORFI program) is gratefully acknowledged. A previous draft of this article was presented at a seminar at UNUMerit, Maastricht, September 2014, a workshop at the University of Oslo, October 2014, seminar at WIIW, Vienna, March 2015, and a seminar at LEM, University of Pisa, June 2016. We wish to thank Dirk Czarnitzki, Michael Landesmann, Alejandro Lavopa, Pierre Mohnen and three anonymous reviewers of this journal for helpful comments and suggestions on the previous draft.

\section{References}

Acs, Z. J., \& Audretsch, D. B. (1988). Innovation in large and small firms: an empirical analysis.

The American Economic Review, 678-690.

Acs, Z. J., \& Audretsch, D. B. (1990). Innovation and small firms. Mit Press.

Aghion, P., et al. (1997). "Competition and growth with step-by-step innovation: an example." European Economic Review, Papers and Proceedings: 771-782.

Aghion, P., et al. (2005). "Competition and innovation: an inverted U relationship." Quarterly Journal of Economics 120(2): 701-728. 
Aghion, P., P. Askenazy, N. Berman, G. Cette, and L. Eymard (2012). "Credit constraints and the cyclicality of R\&D investment: Evidence from France." Journal of the European Economic Association 10(5), 1001-1024.

Angrist, J.D., Pischke, J. (2008). "Mostly Harmless Econometrics: An Empiricist’s Companion.” Princeton University Press.

Arrow, K. (1962). Economic welfare and the allocation of resources for invention. In The rate and direction of inventive activity: Economic and social factors (pp. 609-626). Princeton University Press.

Arvanitis, S. (2013). Micro-econometric approaches to the evaluation of technology-oriented public programmes: a non-technical review of the state of the art. In Link A.N. and N.S. Vonortas, ed., Handbook on the Theory and Practice of Program Evaluation, Cheltenham: Edward Elgar.

Baghana, R. and P. Mohnen (2009). "Effectiveness of R\&D tax incentives in small and large enterprises in Quèbec." Small Business Economics 33: 91-107.

Bound, J., Cummins, C., Griliches, Z., Hall, B.H. and Jaffe, A. (1984) 'Who does R\&D and who patents?', in: Z. Griliches, ed., R\&D patents, and productivity. Chicago: University of Chicago Press for the National Bureau of Economic Research.

Breschi, S., Malerba, F. and Orsenigo, L. (2000). "Technological regimes and Schumpeterian patterns of innovation.” Economic Journal 110 (463): 388-410. 
Cappelen, A., Raknerud, A. and Rybalka, M. (2012): "The effects of R\&D tax credits on patenting and innovations." Research Policy 41: 334-345.

Castellacci, F. (2008). "Technological paradigms, regimes and trajectories: manufacturing and service industries in a new taxonomy of sectoral patterns of innovation." Research Policy 37: 978994.

Castellacci, F. and J. Zheng (2010). "Technological regimes, Schumpeterian patterns of innovation and firm-level productivity growth." Industrial and Corporate Change 19(6): 1829-1865.

Castellacci, F. and Lie, C. M. (2015). "Do the effects of R\&D tax credits vary across industries? A meta-regression analysis", Research Policy, in press.

Cerulli, G. and Poti', B. (2012): "The differential impact of privately and publicly funded R\&D on R\&D investment and innovation: the Italian case." Prometheus 30 (1): 113-149.

Cohen, W. M. (2010). Fifty years of empirical studies of innovative activity and performance. Handbook of the Economics of Innovation, 1, 129-213.

Cohen, W. M., \& Klepper, S. (1996). A reprise of size and R\&D. The Economic Journal, 925-951.

Comanor, W. S. (1967). Market structure, product differentiation, and industrial research. The Quarterly Journal of Economics, 639-657.

Corchuelo, M. B. and E. Martinez-Ros (2009). "The Effects of Fiscal Incentives for R\&D in Spain." Business Economic Series Working Paper 02. 
Czarnitzki, D. and Hussinger, K. (2004): "The link between R\&D subsidies, R\&D spending and technological performance." ZEW Discussion Paper No. 04-56.

Czarnitzki, D., Hanel, P. and Rosa, J. M. (2011): "Evaluating the impact of R\&D tax credits on innovation: A microeconometric study on Canadian firms." Research Policy 40: 217-229.

Czarnitzki, D. and Delanote, J. (2014): "Incorporating innovation subsidies in the CDM framework: empirical evidence from Belgium", paper presented at the CDM model anniversary workshop, Paris, October 2014.

D'Este, P., Iammarino, S., Savona, M., and von Tunzelmann, N. (2012). What hampers innovation? Revealed barriers versus deterring barriers. Research Policy, 41(2), 482-488.

Dosi, G. (1988). “Sources, procedures, and microeconomic effects of innovation”, Journal of Economic Literature, 26 (3): 1120-1171

Geroski, P. A. (1990). "Innovation, Technological Opportunity and Market Structure." Oxford Economic Papers 42(3): 586-602.

Griffith, R., R Harrison and H. Simpson (2006). "Product Market Reform and Innovation in the EU." CEPR Discussion Paper Series No. 5849.

Hall, B. and Van Reenen, J. (2000). "How effective are fiscal incentives for R\&D? A review of the evidence." Research Policy 29: 449-469. 
Hamberg, D. (1964). Size of firm, oligopoly, and research: The evidence. Canadian Journal of Economics and Political Science/Revue canadienne de economiques et science politique, 30(01), 62-75.

Henderson, R., \& Cockburn, I. (1996). Scale, scope, and spillovers: the determinants of research productivity in drug discovery. The Rand journal of economics, 32-59.

Ho, Y. (2006). "Evaluating the effectiveness of state R\&D tax credits." Graduate School of Public and International Affairs, University of Pittsburgh.

Horowitz, I. (1962). Firm size and research activity. Southern Economic Journal, 298-301.

Huang, C.-H. (2009). Three Essays on the Innovation Behaviour of Taiwan's Manufacturing Firms.

Graduate Institute of Industrial Economics, Taiwan, National Central University.

Hughes, W.R. (1971) 'Scale frontiers in electric power', in: W.M. Capron, ed., Technological change in regulated industries. Washington: Brookings Institution

Hægeland, T. and J. Møen (2007). "Input additionality in the Norwegian R\&D tax credit scheme." Statistics Norway Reports.

Lee, C.-Y. (2011). "The differential effects of public R\&D support on firm R\&D: Theory and evidence from multi-country data." Technovation 31(256-269).

Levin, R.C. (1977) 'Technical change and optimal scale: Some evidence and implications', Southern Economic Journal, 44:208-221. 
Levin, R.C. (1978) 'Technical change, barriers to entry, and market structure', Economica, 45:347361.

Lokshin, B. and P. Mohnen (2012). "How effective are level-based R\&D tax credits? Evidence from the Netherlands." Applied Economics 44(12): 1527-1538.

Lunn, J., \& Martin, S. (1986). Market structure, firm structure and research and development. Quarterly Review of Economics and Business, 26(1), 31-44.

Malerba, F. and L. Orsenigo (1996). "Schumpeterian patterns of innovation are technologyspecific." Research Policy 25: 451-478.

Malerba, F. (2002). "Sectoral systems of innovation and production.” Research Policy 31: 247-264.

Mansfield, E. (1968). Industrial research and technological innovation; an econometric analysis. Norton, NY.

Mohnen P. and Rosa, J. (2002). "Barriers to Innovation in Service Industries in Canada". In Institutions and Systems in the Geography of Innovation, by Feldman, M. and Massard, N. (eds), Kluwer Academic Publishers, Boston: 231-250.

Nelson, R. and S. Winter (1982). An Evolutionary Theory of Economic Change. Cambridge, USA: The Belknap Press of Harvard University Press.

Nichols, A. (2007). “Causal inference with observational data.” Stata Journal 7: 507-541. 
Nichols, A. (2008). "Erratum and discussion of propensity-score reweighting." Stata Journal 8: $532-539$.

Nickell, S.J. (1996). "Competition and Corporate Performance." Journal of Political Economy 104 (4): 724-746.

Nicoletti, G. and S. Scarpetta (2004). "Regulation, Productivity and Growth: OECD Evidence." Economic Policy 18: 9-72.

OECD (2010). "R\&D tax incentives: rationale, design, evaluation.", Paris, OECD.

Paff, L. A. (2004). "Does the alternate incremental credit affect firm R\&D?" Technovation 24: 4152.

Paff, L. A. (2005). "State-Level R\&D Tax Credits: A Firm-Level Analysis." Topics in Economic Analysis \& Policy 5(1).

Parsons, M. and Phillips, N. (2007), “An Evaluation of the Federal Tax Credit for Scientific Research and Experimental Development.” Department of Finance Working Paper 2007-08

Pavitt, K. (1984). "Sectoral patterns of technical change: towards a taxonomy and a theory." Research Policy 13: 343-373.

Pavitt, K., Robson, M. and Townsend, J. (1987) 'The size distribution of innovating firms in the UK:1945-1983', Journal of Industrial Economics, 35:297-316. 
Phillips, A. (1971) Technology and market structure. Lexington, Mass.: D.C. Heath.

Rao, N. (2013). "Do Tax Credits Stimulate R\&D Spending? The Effects of the R\&D Tax Credit in its First Decade." NYU Wagner Research Paper No. 2272174.

Scherer, F. (1967). "Market Structure and the Employment of Scientists and Engineers." American Economic Review 56: 524-531.

Scherer, F.M., Beckenstein, A., Kaufer, E. and Murphy, R.D. (1975) The economics of multi-plant operation. Cambridge, Mass.: Harvard University Press.

Takalo, T., Tanayama, T. and Toivanen, O. (2013). "Estimating the benefits of targeted R\&D subsidies." The Review of Economics and Statistics 95(1): 255-272.

Tang, J. (2006). "Competition and Innovation Behaviour." Research Policy 35: 68-82.

Tunzelmann, N. V. and V. Acha (2005). Innovation in 'low-tech' industries. The Oxford Handbook of Innovation. J. Fagerberg, D. C. Mowery and R. R. Nelson. Oxford, Oxford University Press.

Wang, J.-C. and K.-H. Tsai (1998). "The impact of research and development promotion schemes in the Taiwanese electronic component industry." R\&D Management 28(2): 119-124.

Wilson, D. J. (2009). "Beggar Thy Neighbor? The In-State, Out-of-State, and Aggregate Effects of R\&D Tax Credits." The Review of Economics and Statistics 91 (2): 431-436. 
Yang, C.-H., et al. (2012). "Tax incentives and R\&D activity: Firm-level evidence from Taiwan." Research Policy 41: 1578-1588.

Yohei, K. (2013). "Effect of R\&D Tax Credits for SMEs in Japan: a microeconometric analysis focused on liquidity constraints." Small Business Economics. 
Table 1: Descriptive statistics (mean values and number of observations)

\begin{tabular}{|c|c|c|c|c|c|c|c|}
\hline Norway & $\begin{array}{l}\text { Whole } \\
\text { sample }\end{array}$ & SB & SS & SI & SD & LC & HC \\
\hline TC & 0.23 & 0.43 & 0.34 & 0.21 & 0.17 & 0.21 & 0.31 \\
\hline RD_INTENSITY & 2.57 & 7.27 & 4.25 & 1.40 & 1.84 & 2.16 & 4.68 \\
\hline TURN_NEW & 8.09 & 16.5 & 12.6 & 6.14 & 6.27 & 7.33 & 12.08 \\
\hline SIZE & 4.42 & 4.61 & 4.32 & 4.52 & 4.34 & 4.40 & 4.52 \\
\hline H_FINANCE_INT & 0.997 & 1.29 & 1.12 & 0.91 & 0.95 & 0.98 & 1.10 \\
\hline H_FINANCE_EXT & 0.87 & 1.07 & 0.99 & 0.83 & 0.81 & 0.85 & 0.94 \\
\hline H_PERSONNENEL & 0.89 & 1.11 & 1.14 & 0.85 & 0.80 & 0.88 & 0.94 \\
\hline COOP & 0.22 & 0.42 & 0.28 & 0.20 & 0.18 & 0.21 & 0.30 \\
\hline EXPORT & 0.29 & 0.55 & 0.44 & 0.27 & 0.20 & 0.26 & 0.43 \\
\hline GROUP & 0.42 & 0.52 & 0.40 & 0.42 & 0.40 & 0.41 & 0.46 \\
\hline $\begin{array}{c}\text { Observations } \\
(\%)\end{array}$ & $\begin{array}{c}7194 \\
(100 \%)\end{array}$ & $\begin{array}{c}729 \\
(10.1 \%)\end{array}$ & $\begin{array}{c}928 \\
(12.9 \%)\end{array}$ & $\begin{array}{c}2221 \\
(30.9 \%)\end{array}$ & $\begin{array}{c}3316 \\
(46.1 \%)\end{array}$ & $\begin{array}{c}6055 \\
(84.4 \%)\end{array}$ & $\begin{array}{c}1118 \\
(15.6 \%)\end{array}$ \\
\hline \multicolumn{8}{|l|}{ Italy } \\
\hline TC & 0.12 & 0.14 & 0.14 & 0.12 & 0.10 & 0.12 & 0.11 \\
\hline RD_INTENSITY & 1.80 & 2.78 & 2.55 & 1.58 & 1.43 & 1.81 & 1.79 \\
\hline TURN_NEW & 9.64 & 11.82 & 11.90 & 7.63 & 9.91 & 9.84 & 9.09 \\
\hline SIZE & 3.54 & 3.70 & 3.68 & 3.52 & 3.46 & 3.52 & 3.60 \\
\hline H_FINANCE_INT & 1.44 & 1.56 & 1.42 & 1.59 & 1.28 & 1.41 & 1.51 \\
\hline H_FINANCE_EX'T & 1.00 & 0.91 & 0.90 & 0.97 & 1.09 & 1.02 & 0.95 \\
\hline H_PERSONN̄EL & 1.03 & 1.35 & 1.26 & 0.94 & 0.93 & 1.02 & 1.04 \\
\hline COOP & 0.16 & 0.20 & 0.21 & 0.14 & 0.15 & 0.16 & 0.15 \\
\hline EXPORT & 0.67 & 0.69 & 0.81 & 0.59 & 0.67 & 0.70 & 0.58 \\
\hline GROUP & 0.20 & 0.28 & 0.27 & 0.19 & 0.16 & 0.19 & 0.23 \\
\hline $\begin{array}{c}\text { Observations } \\
(\%)\end{array}$ & $\begin{array}{c}9136 \\
(100 \%)\end{array}$ & $\begin{array}{c}976 \\
(10.7 \%)\end{array}$ & $\begin{array}{c}1442 \\
(15.8 \%)\end{array}$ & $\begin{array}{c}3141 \\
(34.4 \%)\end{array}$ & $\begin{array}{c}3577 \\
(39.1 \%)\end{array}$ & $\begin{array}{c}6715 \\
(73.5 \%)\end{array}$ & $\begin{array}{c}2421 \\
(26.5 \%)\end{array}$ \\
\hline \multicolumn{8}{|l|}{ France } \\
\hline TC & 0.32 & 0.43 & 0.43 & 0.299 & 0.197 & 0.27 & 0.38 \\
\hline RD_INTENSITY & 3.67 & 5.13 & 4.18 & 3.17 & 2.84 & 3.00 & 4.58 \\
\hline TURN_NEW & 16.86 & 17.93 & 19.5 & 16.22 & 15.43 & 15.21 & 19.11 \\
\hline SIZ̄E & 5.16 & 5.358 & 5.14 & 5.29 & 4.855 & 5.11 & 5.22 \\
\hline H_FINANCE_INT & 1.62 & 1.645 & 1.63 & 1.68 & 1.53 & 1.55 & 1.71 \\
\hline H_FINANCE_EXT & 0.93 & 0.943 & 1.63 & 0.98 & 0.89 & 0.89 & 0.98 \\
\hline H_PERSONN̄EL & 1.34 & 1.24 & 1.4 & 1.42 & 1.29 & 1.38 & 1.28 \\
\hline COOP & 0.42 & 0.53 & 0.47 & 0.41 & 0.33 & 0.39 & 0.47 \\
\hline EXPORT & 0.85 & 0.90 & 0.91 & 0.84 & 0.78 & 0.82 & 0.88 \\
\hline GROUP & 0.74 & 0.82 & 0.76 & 0.76 & 0.64 & 0.72 & 0.77 \\
\hline $\begin{array}{c}\text { Observations } \\
(\%)\end{array}$ & $\begin{array}{c}7288 \\
(100 \%)\end{array}$ & $\begin{array}{c}1655 \\
(22.7 \%)\end{array}$ & $\begin{array}{c}1080 \\
(14.8 \%)\end{array}$ & $\begin{array}{c}2400 \\
(32.9 \%)\end{array}$ & $\begin{array}{c}2153 \\
(29.5 \%)\end{array}$ & $\begin{array}{c}4206 \\
(57.7 \%)\end{array}$ & $\begin{array}{c}3082 \\
(42.3 \%)\end{array}$ \\
\hline
\end{tabular}


Table 2: Correlation coefficients

\begin{tabular}{|c|c|c|c|c|c|c|c|c|c|c|c|}
\hline & & TC & $\frac{\text { RD_}_{-}}{\text {INTENSITY }}$ & $\begin{array}{l}\text { TURN } \\
\text { NEW }\end{array}$ & SIZE & $\begin{array}{c}\mathrm{H}_{-} \\
\text {FINANCE } \\
\text { INT }\end{array}$ & $\begin{array}{c}\mathrm{H}_{-} \\
\text {FINANCE } \\
\text { EXT }\end{array}$ & $\begin{array}{c}\mathrm{H}_{-} \\
\text {PERS } \\
\text { ONNEL }\end{array}$ & COOP & EXPORT & GROUP \\
\hline & TC & 1.000 & & & & & & & & & \\
\hline & RD_INTENSITY & 0.048 & 1,000 & & & & & & & & \\
\hline & TURN_NEW & 0.233 & -0.003 & 1.000 & & & & & & & \\
\hline & SIZE & 0.110 & -0.005 & 0.036 & 1.000 & & & & & & \\
\hline \multirow[t]{10}{*}{ Norway } & H_FINANCE_INT & 0.232 & 0.044 & 0.178 & 0.055 & 1.000 & & & & & \\
\hline & H_FINANCE_EXT & 0.236 & 0.049 & 0.177 & 0.034 & 0.791 & 1.000 & & & & \\
\hline & H_PERSONNENEL & 0.226 & 0.022 & 0.187 & 0.078 & 0.569 & 0.552 & 1.000 & & & \\
\hline & COOP & 0.405 & 0.032 & 0.257 & 0.187 & 0.257 & 0.235 & 0.235 & 1.000 & & \\
\hline & EXPORT & 0.325 & 0.196 & 0.226 & 0.141 & 0.186 & 0.170 & 0.163 & 0.283 & 1.000 & \\
\hline & GROUP & 0.139 & -0.027 & 0.063 & 0.241 & 0.054 & 0.031 & 0.057 & 0.188 & 0.262 & 1.000 \\
\hline & TC & 1 & & & & & & & & & \\
\hline & RD_INTENSITY & 0.202 & 1 & & & & & & & & \\
\hline & TÜRN_NEW & 0.067 & 0.259 & 1 & & & & & & & \\
\hline & SIZ̄E & 0.041 & -0.025 & 0.045 & 1 & & & & & & \\
\hline \multirow[t]{10}{*}{ Italy } & H_FINANCE_INT & 0.008 & -0.018 & -0.021 & 0.126 & 1 & & & & & \\
\hline & H_FINANCE_EXT & 0.012 & 0.064 & 0.003 & -0.042 & -0.274 & 1 & & & & \\
\hline & H_PERSONNĒEL & 0.117 & 0.174 & 0.087 & 0.132 & 0.023 & -0.004 & 1 & & & \\
\hline & COOP & 0.056 & 0.214 & 0.128 & 0.163 & 0.029 & 0.008 & 0.154 & 1 & & \\
\hline & EXPORT & 0.059 & 0.099 & 0.124 & 0.239 & -0.009 & 0.001 & 0.142 & 0.121 & 1 & \\
\hline & GROUP & 0.020 & 0.032 & 0.026 & 0.405 & 0.048 & -0.055 & 0.137 & 0.093 & 0.094 & 1 \\
\hline & TC & 1 & & & & & & & & & \\
\hline & RD_INTENSITY & 0.132 & 1 & & & & & & & & \\
\hline & TURN_NEW & 0.131 & 0.112 & 1 & & & & & & & \\
\hline & SIZE & 0.244 & -0.026 & 0.034 & 1 & & & & & & \\
\hline \multirow[t]{6}{*}{ France } & H_FINANCE_INT & 0.064 & 0.052 & 0.034 & -0.081 & 1 & & & & & \\
\hline & H_FINANCE_EXT & 0.079 & 0.047 & 0.040 & 0.005 & 0.491 & 1 & & & & \\
\hline & H_PERSONN̄EL & 0.032 & -0.009 & 0.002 & -0.060 & 0.300 & 0.232 & 1 & & & \\
\hline & COOP & 0.253 & 0.094 & 0.189 & 0.302 & 0.050 & 0.064 & 0.016 & 1 & & \\
\hline & EXPORT & 0.172 & 0.034 & 0.064 & 0.244 & 0.021 & 0.030 & 0.015 & 0.148 & 1 & \\
\hline & GROUP & 0.103 & -0.042 & 0.023 & 0.484 & -0.065 & 0.001 & -0.069 & 0.197 & 0.194 & 1 \\
\hline
\end{tabular}


Table 3: Results for equation 1:. Dependent variable: R\&D tax credit dummy. Estimation method: panel random effects probit.

3a: Specification 1 (full sample)

\begin{tabular}{|c|c|c|c|c|c|c|}
\hline & Nor & vay & & & & \\
\hline & Coeff. & Marg. Eff. & Coeff. & Marg. Eff. & Coeff. & Marg. Eff. \\
\hline SB & 0.809 & 0.134 & 0.127 & 0.021 & 0.755 & 0.196 \\
\hline & $(7.29)^{* * *}$ & $(7.67)^{* * *}$ & $(1.94)^{*}$ & $(1.95)^{*}$ & $(9.01)^{* * *}$ & $(9.55)^{* * *}$ \\
\hline SS & 0.571 & 0.094 & 0.115 & 0.019 & 0.888 & 0.228 \\
\hline & $(5.64)^{* * *}$ & $(5.78)^{* * *}$ & $(2.02)^{* *}$ & $(2.03)^{* *}$ & $(10.34)^{* * *}$ & $(10.89)^{* * *}$ \\
\hline SI & 0.084 & 0.014 & 0.064 & 0.011 & 0.877 & 0.067 \\
\hline & $(1.07)$ & $(1.07)$ & $(1.39)$ & $(1.39)$ & $(10.2)^{* * *}$ & $(3.61)^{* * *}$ \\
\hline LC & -0.147 & -0.024 & 0.026 & 0.004 & -0.196 & -0.049 \\
\hline & $(-1.66)^{*}$ & $(-1.67)^{*}$ & $(0.59)$ & $(0.59)$ & $(-3.42)^{* * *}$ & $(-3.27)^{* * *}$ \\
\hline SIZE & 0.278 & 0.046 & 0.094 & 0.016 & 0.257 & 0.089 \\
\hline & $(8.31)^{* * *}$ & $(8.75)^{* * *}$ & $(4.58) * * *$ & $(4.70) * * *$ & $(3.59)^{* * *}$ & $(15.77)^{* * *}$ \\
\hline H_FINANCE_INT & 0.107 & 0.018 & 0.047 & 0.008 & 0.084 & 0.022 \\
\hline & $(2.57) * *$ & $(2.56)^{* *}$ & $(2.31)^{* *}$ & $(2.33)^{* *}$ & $(3.05) * * *$ & $(3.04)^{* * *}$ \\
\hline H_FINANCE_EXT & 0.204 & 0.034 & 0.035 & 0.006 & -0.187 & 0.018 \\
\hline & $(4.83) * * *$ & $(4.83)^{* * *}$ & $(2.04)^{* *}$ & $(2.04)^{* *}$ & $(-3.26) * * *$ & $(2.58)^{* * *}$ \\
\hline H_PERSONNEL & 0.179 & 0.029 & 0.130 & 0.022 & 0.044 & 0.012 \\
\hline & $(5.13)^{* * *}$ & $(5.11)^{* * *}$ & $(7.80)^{* * *}$ & $(8.20)^{* * *}$ & $(1.66)^{*}$ & $(1.66)^{*}$ \\
\hline EXPORT & 0.765 & 0.126 & 0.162 & 0.027 & 0.343 & 0.173 \\
\hline & $(11.18)^{* * *}$ & $(11.28)^{* * *}$ & $(3.60)^{* * *}$ & $(3.64)^{* * *}$ & $(14)^{* * *}$ & $(8.37)^{* * *}$ \\
\hline GROUP & 0.057 & 0.009 & -0.014 & -0.002 & -0.179 & -0.047 \\
\hline & $(0.77)$ & $(0.77)$ & $(-0.27)$ & $(-0.27)$ & $(-2.74) * * *$ & $(-2.75)^{* * *}$ \\
\hline $\mathbf{N}$ & 6484 & & 9136 & & 7288 & \\
\hline LR test for rho $=0$ & $328.40 * * *$ & & $1.65^{*}$ & & $270.73 * * *$ & \\
\hline McKelvey \& Zavoina $\mathbf{R}^{2}$ & 0.2661 & & 0.1421 & & 0.2482 & \\
\hline
\end{tabular}

3b: Specification 2 (with lagged R\&D).

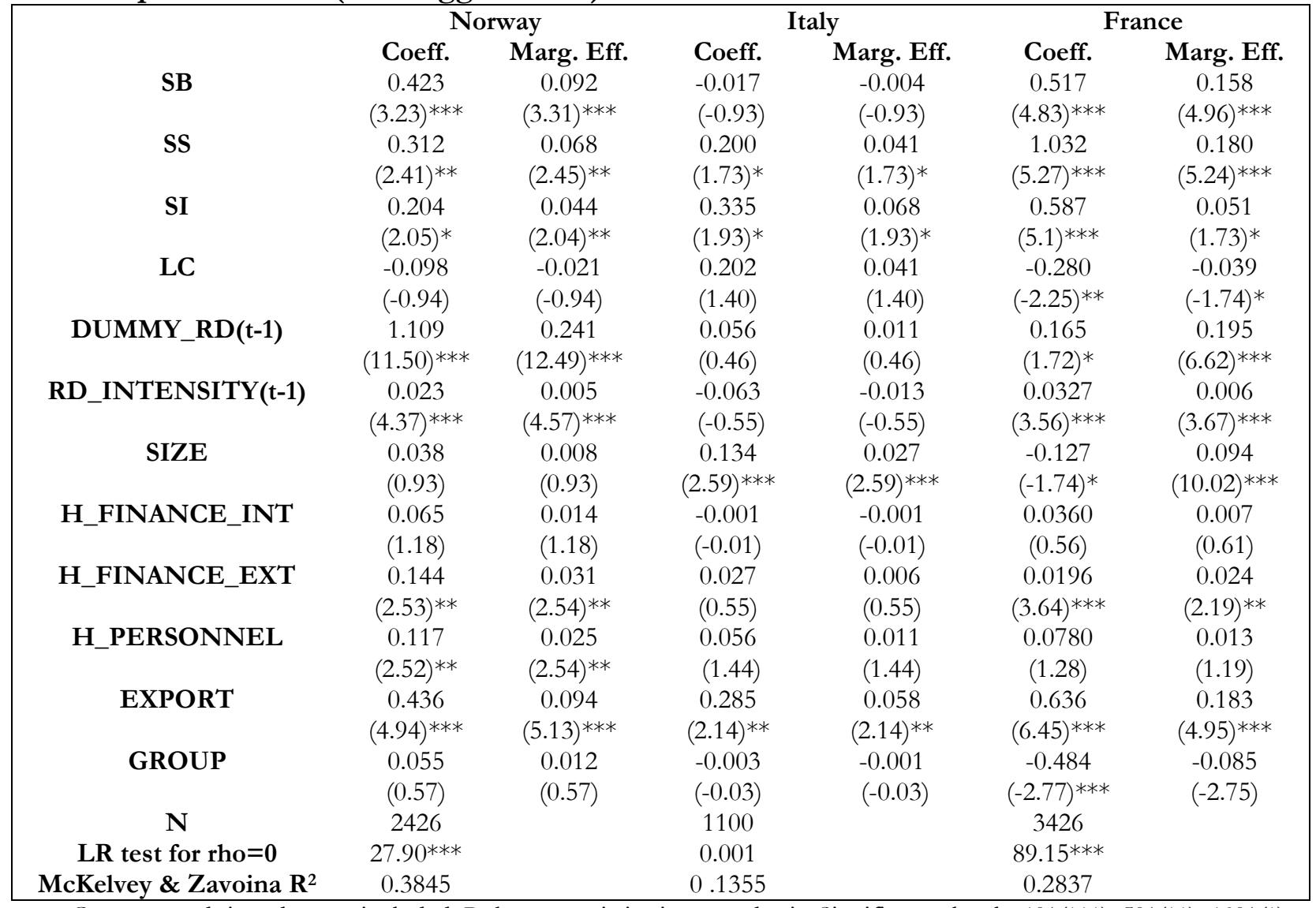

Constant and time dummy included. Robust t-statistics in parenthesis. Significance levels: $1 \%(* * *), 5 \%(* *), 10 \%(*)$. 
Table 4a: Matching results for equation 2 (input additionality). Outcome variable: R\&D intensity. Specification 1 (full sample).

\begin{tabular}{|c|c|c|c|c|c|c|c|c|}
\hline & & & SB & SS & SI & SD & LC & HC \\
\hline \multirow[t]{3}{*}{ Norway } & Year 2004 & $\begin{array}{c}\text { ATT } \\
\text { t-stat } \\
\mathrm{N} \text { control } \\
\mathrm{N} \text { treated } \\
\text { Median bias }\end{array}$ & $\begin{array}{c}5.275 \\
(2.95)^{* * *} \\
100 \\
76 \\
3.4 \%\end{array}$ & $\begin{array}{c}7.767 \\
(6.34)^{* * *} \\
112 \\
114 \\
2.8 \%\end{array}$ & $\begin{array}{c}3.744 \\
(7.26)^{* * *} \\
363 \\
151 \\
4.1 \%\end{array}$ & $\begin{array}{c}2.417 \\
(3.24)^{* * *} \\
515 \\
179 \\
3.1 \%\end{array}$ & $\begin{array}{c}3.845 \\
(8.76)^{* * *} \\
918 \\
414 \\
2.3 \%\end{array}$ & $\begin{array}{c}7.670 \\
(5.20)^{* * *} \\
172 \\
105 \\
7.3 \%\end{array}$ \\
\hline & Year 2006 & $\begin{array}{c}\text { ATT } \\
\text { t-stat } \\
\mathrm{N} \text { control } \\
\mathrm{N} \text { treated } \\
\text { Median bias }\end{array}$ & $\begin{array}{c}10.835 \\
(5.28)^{* * *} \\
113 \\
92 \\
4.3 \%\end{array}$ & $\begin{array}{c}8.790 \\
(5.18)^{* * *} \\
239 \\
109 \\
4.9 \%\end{array}$ & $\begin{array}{c}5.091 \\
(6.39)^{* * *} \\
620 \\
149 \\
3.1 \%\end{array}$ & $\begin{array}{c}4.530 \\
(5.12)^{* * *} \\
1016 \\
151 \\
1.5 \%\end{array}$ & $\begin{array}{c}6.484 \\
(10.21)^{* * *} \\
1770 \\
396 \\
0.9 \%\end{array}$ & $\begin{array}{c}8.381 \\
(3.89)^{* * *} \\
218 \\
103 \\
4.0 \%\end{array}$ \\
\hline & Year 2008 & $\begin{array}{c}\text { ATT } \\
\text { t-stat } \\
\mathrm{N} \text { control } \\
\mathrm{N} \text { treated } \\
\text { Median bias }\end{array}$ & $\begin{array}{c}9.418 \\
(4.41)^{* * *} \\
170 \\
121 \\
3.4 \%\end{array}$ & $\begin{array}{c}6.810 \\
(3.86)^{* * *} \\
198 \\
65 \\
3.1 \%\end{array}$ & $\begin{array}{c}3.809 \\
(5.23)^{* * *} \\
580 \\
112 \\
3.6 \%\end{array}$ & $\begin{array}{c}11.02 \\
(7.36)^{* * *} \\
957 \\
166 \\
3.4 \%\end{array}$ & $\begin{array}{c}8.051 \\
(8.75)^{* * *} \\
1591 \\
356 \\
1.0 \%\end{array}$ & $\begin{array}{c}9.690 \\
(5.49)^{* * *} \\
300 \\
100 \\
1.6 \%\end{array}$ \\
\hline \multirow[t]{3}{*}{ Italy } & Year 2004 & $\begin{array}{c}\text { ATT } \\
\text { t-stat } \\
\mathrm{N} \text { control } \\
\mathrm{N} \text { treated } \\
\text { Median bias }\end{array}$ & $\begin{array}{c}2.969 \\
(1.67)^{*} \\
296 \\
18 \\
6.5 \%\end{array}$ & $\begin{array}{c}4.036 \\
(2.60)^{* * *} \\
392 \\
25 \\
5.9 \%\end{array}$ & $\begin{array}{c}2.783 \\
(2.60)^{* * *} \\
835 \\
35 \\
4.3 \%\end{array}$ & $\begin{array}{c}1.006 \\
(2.43)^{* *} \\
1152 \\
30 \\
2.3 \%\end{array}$ & $\begin{array}{c}2.276 \\
(4.34)^{* * *} \\
1986 \\
88 \\
2.5 \%\end{array}$ & $\begin{array}{c}5.477 \\
(2.47)^{* *} \\
689 \\
20 \\
4.5 \%\end{array}$ \\
\hline & Year 2006 & $\begin{array}{c}\text { ATT } \\
\text { t-stat } \\
\mathrm{N} \text { control } \\
\mathrm{N} \text { treated } \\
\text { Median bias }\end{array}$ & $\begin{array}{c}-0.897 \\
(-2.26)^{* *} \\
350 \\
44 \\
3.5 \%\end{array}$ & $\begin{array}{c}-1.103 \\
(-3.70)^{* * *} \\
557 \\
73 \\
3.3 \%\end{array}$ & $\begin{array}{c}-0.451 \\
(-3.81)^{* * *} \\
1054 \\
178 \\
2.6 \%\end{array}$ & $\begin{array}{c}-0.445 \\
(-1.72)^{*} \\
1168 \\
181 \\
0.4 \%\end{array}$ & $\begin{array}{c}-0.611 \\
(-3.45)^{* * *} \\
2264 \\
325 \\
1.7 \%\end{array}$ & $\begin{array}{c}-0.560 \\
(-3.94)^{* * *} \\
865 \\
149 \\
3.1 \%\end{array}$ \\
\hline & Year 2008 & $\begin{array}{c}\text { ATT } \\
\text { t-stat } \\
\mathrm{N} \text { control } \\
\mathrm{N} \text { treated } \\
\text { Median bias }\end{array}$ & $\begin{array}{c}6.619 \\
(5.71)^{* * *} \\
195 \\
72 \\
4.3 \%\end{array}$ & $\begin{array}{c}4.268 \\
(5.00)^{* * *} \\
294 \\
100 \\
1.9 \%\end{array}$ & $\begin{array}{c}5.722 \\
(7.39)^{* * *} \\
886 \\
151 \\
1.4 \%\end{array}$ & $\begin{array}{c}3.357 \\
(6.14)^{* * *} \\
903 \\
143 \\
1.9 \%\end{array}$ & $\begin{array}{c}4.483 \\
(10.37) * * * \\
1682 \\
367 \\
2.1 \%\end{array}$ & $\begin{array}{c}5.937 \\
(5.10)^{* * *} \\
596 \\
101 \\
4.0 \%\end{array}$ \\
\hline \multirow[t]{3}{*}{ France } & Year 2004 & $\begin{array}{c}\text { ATT } \\
\text { t-stat } \\
\mathrm{N} \text { control } \\
\mathrm{N} \text { treated } \\
\text { Median bias }\end{array}$ & $\begin{array}{c}3.45 \\
(4.73)^{* * *} \\
451 \\
268 \\
1.8 \%\end{array}$ & $\begin{array}{c}2.06 \\
(2.59)^{* * *} \\
330 \\
204 \\
2.9 \%\end{array}$ & $\begin{array}{c}1.53 \\
(2.66)^{* * *} \\
291 \\
844 \\
3.2 \%\end{array}$ & $\begin{array}{c}0.88 \\
(1.28) \\
704 \\
149 \\
2.9 \%\end{array}$ & $\begin{array}{c}1.44 \\
(4.1)^{* * *} \\
1,365 \\
423 \\
0.3 \%\end{array}$ & $\begin{array}{c}3.08 \\
(5.35)^{* * *} \\
964 \\
489 \\
3.2 \%\end{array}$ \\
\hline & Year 2006 & $\begin{array}{c}\text { ATT } \\
\text { t-stat } \\
\mathrm{N} \text { control } \\
\mathrm{N} \text { treated } \\
\text { Median bias }\end{array}$ & $\begin{array}{c}3.45 \\
(6.16)^{* * *} \\
278 \\
324 \\
1.1 \%\end{array}$ & $\begin{array}{c}2.48 \\
(3.79)^{* * *} \\
191 \\
208 \\
1.98 \%\end{array}$ & $\begin{array}{c}2.39 \\
(1.24) \\
522 \\
319 \\
1.4 \%\end{array}$ & $\begin{array}{c}-0.21 \\
(-0.45) \\
738 \\
217 \\
2 \%\end{array}$ & $\begin{array}{c}0.15 \\
(0.42) \\
1,115 \\
522 \\
1.2 \%\end{array}$ & $\begin{array}{c}3.00 \\
(6.42)^{* * *} \\
614 \\
546 \\
1.4 \%\end{array}$ \\
\hline & Year 2008 & $\begin{array}{c}\text { ATT } \\
\text { t-stat } \\
\mathrm{N} \text { control } \\
\mathrm{N} \text { treated } \\
\text { Median bias }\end{array}$ & $\begin{array}{c}4.21 \\
(5.52)^{* * *} \\
221 \\
113 \\
2.2 \%\end{array}$ & $\begin{array}{c}1.82 \\
(2.5)^{* * *} \\
88 \\
54 \\
3.3 \%\end{array}$ & $\begin{array}{c}1.84 \\
(2.36)^{* * *} \\
318 \\
106 \\
9.2 \%\end{array}$ & $\begin{array}{c}0.25 \\
(0.48) \\
286 \\
59 \\
3.8 \%\end{array}$ & $\begin{array}{c}1.41 \\
(2.8)^{* * *} \\
580 \\
201 \\
1.4 \%\end{array}$ & $\begin{array}{c}4.16 \\
(5.71)^{* * *} \\
338 \\
131 \\
2.2 \%\end{array}$ \\
\hline
\end{tabular}


Table 4b: Matching results for equation 2 (input additionality). Outcome variable: R\&D intensity. Specification 2 (with lagged $R \& D$ ).

\begin{tabular}{|c|c|c|c|c|c|c|c|}
\hline Norway & & SB & SS & SI & SD & LC & $\mathrm{HC}$ \\
\hline \multirow[t]{5}{*}{ Year 2006} & ATT & 1.944 & 4.381 & 3.149 & 1.383 & 3.449 & 1.045 \\
\hline & t-stat & $(0.98)$ & $(2.90)^{* * *}$ & $(4.82)^{* * *}$ & $(2.34)^{* *}$ & $(7.83)^{* * *}$ & $(0.48)$ \\
\hline & $\mathrm{N}$ control & 72 & 99 & 271 & 380 & 693 & 129 \\
\hline & $\mathrm{N}$ treated & 72 & 77 & 110 & 107 & 274 & 92 \\
\hline & Median bias & $4.1 \%$ & $4.7 \%$ & $5.4 \%$ & $3.0 \%$ & $3.9 \%$ & $3.4 \%$ \\
\hline \multirow[t]{5}{*}{ Year 2008} & ATT & 2.325 & 3.541 & 2.414 & 3.501 & 3.447 & 3.660 \\
\hline & t-stat & $(0.90)$ & $(4.87)^{* * *}$ & $(4.53)^{* * *}$ & $(2.68) * * *$ & $(5.13)^{* * *}$ & $(1.96)^{*}$ \\
\hline & $\mathrm{N}$ control & 93 & 99 & 296 & 444 & 797 & 129 \\
\hline & $\mathrm{N}$ treated & 87 & 51 & 87 & 81 & 230 & 71 \\
\hline & Median bias & $3.4 \%$ & $5.0 \%$ & $6.0 \%$ & $6.4 \%$ & $6.2 \%$ & $6.0 \%$ \\
\hline Italy & & SB & SS & SI & SD & LC & $\mathrm{HC}$ \\
\hline \multirow[t]{5}{*}{ Year 2006} & ATT & -1.555 & -0.509 & -0.609 & -0.333 & -0.340 & -0.279 \\
\hline & t-stat & $(-1.33)$ & $(-1.55)$ & $(-1.75)^{*}$ & $(-0.80)$ & $(-1.00)$ & $(-0.89)^{* * *}$ \\
\hline & $\mathrm{N}$ control & 49 & 119 & 194 & 255 & 466 & 161 \\
\hline & $\mathrm{N}$ treated & 5 & 12 & 18 & 24 & 41 & 19 \\
\hline & Median bias & $11.2 \%$ & $6.1 \%$ & $7.3 \%$ & $3.2 \%$ & $3.2 \%$ & $4.7 \%$ \\
\hline \multirow[t]{5}{*}{ Year 2008} & ATT & 8.168 & 3.728 & 5.143 & 4.265 & 4.091 & 11.383 \\
\hline & t-stat & $(2.81) * * *$ & $(2.05)^{* * *}$ & $(2.69)^{* * *}$ & $(2.25)^{* *}$ & $(4.19)^{* * *}$ & $(3.34)^{* * *}$ \\
\hline & $\mathrm{N}$ control & 22 & 33 & 134 & 137 & 240 & 91 \\
\hline & $\mathrm{N}$ treated & 13 & 16 & 25 & 22 & 65 & 12 \\
\hline & Median bias & $9.5 \%$ & $18.3 \%$ & $3.1 \%$ & $3.8 \%$ & $5.0 \%$ & $9.6 \%$ \\
\hline France & & SB & SS & SI & SD & LC & $\mathrm{HC}$ \\
\hline \multirow[t]{5}{*}{ Year 2006} & ATT & 3.42 & 1.67 & 0.46 & -0.57 & 0.61 & 2.35 \\
\hline & t-stat & $(4.11)^{* * *}$ & $(2.44)^{* *}$ & $(0.85)$ & $(-0.53)$ & $(1.43)^{*}$ & $(3.46)^{* * *}$ \\
\hline & $\mathrm{N}$ control & 148 & 86 & 275 & 211 & 404 & 316 \\
\hline & $\mathrm{N}$ treated & 212 & 129 & 225 & 78 & 280 & 364 \\
\hline & Median bias & $5.3 \%$ & $3.6 \%$ & $2.5 \%$ & $1.3 \%$ & $3 \%$ & $3.3 \%$ \\
\hline \multirow[t]{5}{*}{ Year 2008} & ATT & 2.62 & 1.54 & 1.44 & -0.13 & 1.58 & 2.86 \\
\hline & t-stat & $(2.99)^{* * *}$ & $(2.16)^{* *}$ & $(1.59)^{*}$ & $(-0.18)$ & $(2.86)^{* * *}$ & $(3.25)^{* * *}$ \\
\hline & $\mathrm{N}$ control & 179 & 82 & 261 & 208 & 463 & 262 \\
\hline & $\mathrm{N}$ treated & 111 & 52 & 104 & 47 & 187 & 127 \\
\hline & Median bias & $9.1 \%$ & $5.7 \%$ & $4.4 \%$ & $3.3 \%$ & $1.7 \%$ & $2.3 \%$ \\
\hline
\end{tabular}


Table 5: Results for equation 3. Dependent variable: Turnover from new products (categorical). Estimation method: bootstrap ordered probit random effects.

5a: Specification 1 (full sample).

\begin{tabular}{|c|c|c|c|c|c|c|}
\hline \multirow{3}{*}{$\mathrm{TET} \cdot \mathrm{SB}$} & Norway & Norway & Italy & Italy & France & France \\
\hline & 0.027 & & 0.033 & & 0.014 & \\
\hline & $(4.77)^{* * *}$ & & $(3.24)^{* * *}$ & & $(3.64)^{* * *}$ & \\
\hline \multirow{2}{*}{ TET $\bullet S S$} & 0.036 & & 0.048 & & 0.028 & \\
\hline & $(4.47)^{* * *}$ & & $(4.71)^{* * *}$ & & $(5.83)^{* * *}$ & \\
\hline \multirow{2}{*}{$\mathrm{TET} \cdot \mathrm{SI}$} & 0.051 & & 0.032 & & 0.024 & \\
\hline & $(3.95) * * *$ & & $(3.86)^{* * *}$ & & $(4.41)^{* * *}$ & \\
\hline $\mathrm{TET} \cdot \mathrm{SD}$ & $\begin{array}{c}0.047 \\
(7.83) * * *\end{array}$ & & $\begin{array}{c}0.039 \\
(3.09)^{* * *}\end{array}$ & & $\begin{array}{c}0.030 \\
(3.68) * * *\end{array}$ & \\
\hline \multirow{2}{*}{ TET • LC } & & 0.035 & & 0.040 & & 0.030 \\
\hline & & $(6.57)^{* * *}$ & & $(6.06) * * *$ & & $(5.45) * * *$ \\
\hline $\mathrm{TET} \cdot \mathrm{HC}$ & & $\begin{array}{c}0.019 \\
(3.22)^{* * *}\end{array}$ & & $\begin{array}{c}0.031 \\
(3.52)^{* * *}\end{array}$ & & $\begin{array}{c}0.018 \\
(5.52)^{* * *}\end{array}$ \\
\hline \multirow{2}{*}{ RD_COUNTER } & 0.049 & 0.016 & 0.045 & 0.046 & 0.029 & 0.030 \\
\hline & $(8.08) * * *$ & $(3.56)^{* * *}$ & $(5.45)^{* * *}$ & $(5.49)^{* * *}$ & $(6.38)^{* * *}$ & $(7.04)^{* * *}$ \\
\hline \multirow{2}{*}{ SIZE } & 0.127 & 0.123 & 0.074 & 0.074 & 0.022 & 0.021 \\
\hline & $(5.48)^{* * *}$ & $(5.65)^{* * *}$ & $(4.98) * * *$ & $(4.92) * * *$ & $(1.49)$ & $(1.36)$ \\
\hline \multirow{2}{*}{ COOP } & 0.995 & 1.031 & 0.548 & 0.547 & 0.92 & 0.920 \\
\hline & $(21.34) * * *$ & $(20.27)^{* * *}$ & $(13.85)^{* * *}$ & $(13.12)^{* * *}$ & $(25.48)^{* * *}$ & $(24.16)^{* * *}$ \\
\hline \multirow{2}{*}{ EXPORT } & 0.497 & 0.532 & 0.471 & 0.472 & 0.263 & 0.264 \\
\hline & $(8.44)^{* * *}$ & $(9.42)^{* * *}$ & $(12.64)^{* * *}$ & $(12.29)^{* * *}$ & $(5.42)^{* * *}$ & $(5.09)^{* * *}$ \\
\hline \multirow{2}{*}{ GROUP } & 0.013 & -0.001 & -0.005 & -0.005 & -0.006 & -0.005 \\
\hline & $(0.26)$ & $(-0.02)$ & $(-0.13)$ & $(-0.13)$ & $(-0.14)$ & $(-0.10)$ \\
\hline Equality of interactions & $6.23^{*}$ & $4.13^{* *}$ & 1.74 & 0.68 & $8.56^{* * *}$ & $4.83^{*}$ \\
\hline $\mathbf{N}$ & 6720 & 6699 & 9136 & 9136 & 7288 & 7288 \\
\hline
\end{tabular}

5b: Specification 2 (with lagged R\&D).

\begin{tabular}{|c|c|c|c|c|c|c|}
\hline \multirow{3}{*}{$\mathrm{TET} \cdot \mathrm{SB}$} & Norway & Norway & Italy & Italy & France & France \\
\hline & $0.027^{\circ}$ & & 0.030 & & 0.019 & \\
\hline & $(2.77)^{* *}$ & & $(1.40)$ & & $(3.37)^{* * *}$ & \\
\hline \multirow{2}{*}{ TET $\bullet \mathrm{SS}$} & 0.028 & & 0.041 & & 0.016 & \\
\hline & $(2.42)^{* *}$ & & (0.98) & & $(1.81)^{*}$ & \\
\hline \multirow{2}{*}{$\mathrm{TET} \cdot \mathrm{SI}$} & 0.072 & & 0.038 & & 0.014 & \\
\hline & $(3.86) * * *$ & & $(2.18)^{* *}$ & & $(1.77)^{*}$ & \\
\hline \multirow{2}{*}{$\mathrm{TET} \cdot \mathrm{SD}$} & 0.025 & & 0.019 & & 0.048 & \\
\hline & $(1.32)$ & & $(0.57)$ & & $(3.55)^{* * *}$ & \\
\hline \multirow{2}{*}{ TET $\bullet$ LC } & & 0.023 & & 0.032 & & 0.009 \\
\hline & & $(2.75)^{* * *}$ & & $(2.40)^{* *}$ & & $(1.41)$ \\
\hline \multirow{2}{*}{ TET $\bullet$ HC } & & 0.013 & & 0.033 & & 0.013 \\
\hline & & $(1.56)$ & & $(1.46)$ & & $(2.86)^{* * *}$ \\
\hline \multirow{2}{*}{ RD_COUNTER } & 0.037 & 0.019 & 0.039 & 0.039 & 0.020 & 0.010 \\
\hline & $(4.26)^{* * *}$ & $(3.40)^{* * *}$ & (1.61) & $(2.08)^{* *}$ & $(3.40)^{* * *}$ & $(1.52)$ \\
\hline \multirow{2}{*}{ SIZE } & 0.118 & 0.113 & 0.133 & 0.134 & 0.029 & 0.038 \\
\hline & $(4.75)^{* * *}$ & $(4.25)^{* * *}$ & $(2.58)^{* * *}$ & $(2.74)^{* * *}$ & $(1.22)$ & $(1.52)$ \\
\hline \multirow{2}{*}{ COOP } & 1.107 & 1.140 & 0.406 & 0.408 & 0.901 & 0.907 \\
\hline & $(16.61)^{* * *}$ & $(17.56)^{* * *}$ & $(3.48) * * *$ & $(3.73)^{* * *}$ & $(16.80)^{* * *}$ & $(16.36)^{* * *}$ \\
\hline \multirow{2}{*}{ EXPORT } & 0.474 & 0.492 & 0.413 & 0.416 & 0.237 & 0.240 \\
\hline & $(6.37)^{* * *}$ & $(8.66)^{* * *}$ & $(2.90)^{* * *}$ & $(3.04)^{* * *}$ & $(2.67) * * *$ & $(2.68)^{* * *}$ \\
\hline \multirow{2}{*}{ GROUP } & 0.050 & 0.058 & -0.133 & -0.134 & -0.130 & -0.139 \\
\hline & $(0.71)$ & (1.01) & $(-1.01)$ & $(-1.06)$ & $(-1.64)$ & $(-1.69)^{*}$ \\
\hline Equality of interactions & 4.64 & 0.62 & 0.37 & 0.01 & 5.56 & 0.17 \\
\hline $\mathbf{N}$ & 4762 & 4743 & 1110 & 1110 & 3426 & 3426 \\
\hline
\end{tabular}

Sectoral group dummies and time dummies included. Bootstrap t-statistics in parenthesis (400 replications). Signif.: $1 \%(* * *), 5 \%(* *), 10 \%(*)$. 
Table 6: Robustness analysis: Comparing results of hypotheses tests for four different econometric specifications and across countries

\begin{tabular}{|c|c|c|c|c|}
\hline & Norway & Italy & France & Overall pattern \\
\hline \multicolumn{5}{|l|}{ Hypothesis 1a } \\
\hline Specification 1 & SB and SS & SB and SS & $\mathrm{SB}$ and $\mathrm{SS}$ & \multirow{4}{*}{$\begin{array}{l}\text { H1a confirmed. } \\
\text { Results are robust across } \\
\text { specifications and countries }\end{array}$} \\
\hline Specification 2 & SB and SS & SS and SI & SB and SS & \\
\hline Specification 3 & $\mathrm{SB}$ and SS & SB and SS & SB and SS & \\
\hline Specification 4 & SB and SS & SB and SS & SB and SS & \\
\hline \multicolumn{5}{|l|}{ Hypothesis 2 a } \\
\hline Specification 1 & $\mathrm{HC}$ & Not significant & $\mathrm{HC}$ & \multirow{4}{*}{$\begin{array}{l}\text { H2a confirmed } \\
\text { only for France }\end{array}$} \\
\hline Specification 2 & Not significant & Not significant & $\mathrm{HC}$ & \\
\hline Specification 3 & Not significant & LC & $\mathrm{HC}$ & \\
\hline Specification 4 & Not significant & Not significant & $\mathrm{HC}$ & \\
\hline \multicolumn{5}{|l|}{ Hypothesis $1 b$} \\
\hline Specification 1 & SB and SS & SB and SS & SB & \multirow{4}{*}{$\begin{array}{l}\text { H1b confirmed. } \\
\text { Results are robust across } \\
\text { specifications and countries }\end{array}$} \\
\hline Specification 2 & SS & SB and SI & SB & \\
\hline Specification 3 & SB and SS & SB, SS and SI & SB & \\
\hline Specification 4 & SB and SS & $\mathrm{SB}, \mathrm{SS}$ and SI & SB & \\
\hline \multicolumn{5}{|l|}{ Hypothesis 2b } \\
\hline Specification 1 & $\mathrm{HC}$ & $\mathrm{HC}$ & $\mathrm{HC}$ & \multirow{4}{*}{$\begin{array}{l}\text { H2b confirmed for France, } \\
\text { and only partly confirmed } \\
\text { for Norway and Italy }\end{array}$} \\
\hline Specification 2 & HC (only 2008) & HC (only 2008) & $\mathrm{HC}$ & \\
\hline Specification 3 & HC (only 2008) & $\mathrm{HC}$ & $\mathrm{HC}$ & \\
\hline Specification 4 & $\mathrm{HC}$ & $\mathrm{HC}$ & $\mathrm{HC}$ & \\
\hline \multicolumn{5}{|l|}{ Hypothesis 1c } \\
\hline Specification 1 & SI & SS & SS and SD & \multirow{4}{*}{$\begin{array}{l}\text { H1c confirmed for Norway } \\
\text { and Italy, and only partly } \\
\text { confirmed for France }\end{array}$} \\
\hline Specification 2 & SI & SS and SI & SD & \\
\hline Specification 3 & SI & SS & SS and SD & \\
\hline Specification 4 & SI & SS & SD & \\
\hline \multicolumn{5}{|l|}{ Hypothesis 2c } \\
\hline Specification 1 & LC & LC & LC & \multirow{4}{*}{$\begin{array}{l}\text { H2c partly supported for } \\
\text { Norway and Italy, } \\
\text { but not for France }\end{array}$} \\
\hline Specification 2 & LC & $\mathrm{HC}$ & $\mathrm{HC}$ & \\
\hline Specification 3 & $\mathrm{LC}$ & $\mathrm{LC}$ & $\mathrm{HC}$ & \\
\hline Specification 4 & LC & LC & $\mathrm{HC}$ & \\
\hline
\end{tabular}

Specifications: 1: baseline (whole sample); 2: including lagged R\&D dummy and lagged R\&D intensity variables; 3: estimated only for innovative firms; 4: estimated only for firms that did not receive R\&D subsidies. 


\section{Appendix: DDD estimates of cross-country differences in IA}

\section{A.1 The R\&D tax credits schemes in Norway, Italy and France}

The Norwegian tax credit scheme (SkatteFUNN) was established in 2002. It is administered by the Research Council of Norway, along with Innovation Norway and the Norwegian Tax Administration. The program initially had a cap limiting the amount eligible for large companies, but this was progressively enlarged in order to attract more large firms. Currently, caps are NOK 5.5 million for R\&D projects done by the firm, and NOK 11 million if the project includes procurement of $R \& D$ services from a public research organization. Eligible R\&D costs are defined by the Research Council of Norway. Companies that are eligible for $\mathrm{R} \& \mathrm{D}$ fiscal incentives have to submit an online application to the Research Council of Norway. This carries out the selection of innovative projects. In our data sample, the share of $\mathrm{R} \& \mathrm{D}$ active companies that receive $\mathrm{R} \& \mathrm{D}$ tax credits amounts to $59 \%$.

The Italian R\&D fiscal incentive program was introduced by the so-called "Visco reform" (Law 140/1997) and first implemented in 1998. The amount of tax credits that can be granted varies depending upon firms' size as well as its regional location (firms located in more depressed areas have higher deduction amounts). Eligible costs under this scheme are $\mathrm{R} \& \mathrm{D}$ labor costs, $\mathrm{R} \& \mathrm{D}$ expenditures for capital and machineries, and costs for technological counselling and the acquisition of external knowledge. Firms that meet the eligibility criteria can apply for the fiscal deduction. In our sample, the share of $\mathrm{R} \& \mathrm{D}$ active firms that receive tax credits is $19 \%$.

In France, R\&D tax credits were first introduced in 1983 targeting all firms that had reported R\&D expenditures independent of size and industry. It is designed as an incremental system: since 2004 , the tax credit was calculated as $45 \%$ of increase in $R \& D$ and $5 \%$ of the current volume of R\&D expenditure. From 2008 (after the end of our investigation period), the tax credit scheme has become volume-based, i.e. it is calculated on the basis of current volume of $R \& D$ expenditures. Eligible $R \& D$ expenditures are $\mathrm{R} \& \mathrm{D}$ wages, amortization of equipment and prototypes, contract research with universities and other public labs, and standardization costs. Any firm can benefit from the tax credit as long as it has eligible R\&D projects and expenses if it sends to the tax authorities a special form stating the details of the project and the eligible R\&D expenses. Research projects are all eligible, while for experimental product development projects only those involving some degree of uncertainty and using scientific methods are 
eligible. In the French data sample used in this paper, 34\% firms that did R\&D received a tax credit.

\section{A.2 Cross-country differences in input additionality effects}

In order to test for cross-country differences in input additionality between Norway, Italy and France, we make use of the so-called difference in difference in difference (DDD) approach (see Angrist and Pischke, 2008). Considering two periods ( $\mathrm{t}=0,1)$ as standard in this type of analysis, we first specify the baseline (diff-in-diff, DD) econometric model:

$\mathrm{RDI}_{\mathrm{it}}=\alpha+\beta$ Treated $_{\mathrm{i}}+\gamma \mathrm{d}_{1}+\eta\left(\right.$ Treated $\left._{\mathrm{ij}} \times \mathrm{d}_{1}\right)+\delta_{I T} \mathrm{IT}+\delta_{\mathrm{NO}} \mathrm{NO}+\theta \mathrm{W}_{\mathrm{ijt}}+\kappa \mathrm{RD}_{\mathrm{j}}+\lambda \mathrm{C}_{\mathrm{j}}+$ $u_{\mathrm{ijt}}$

where $\mathrm{RDI}_{i t}$ (defined as before) is the $\mathrm{R} \& \mathrm{D}$ expenditures as a percentage of total turnover of firm $i$ in period $t$ Treated $_{i}$ is a dummy variable that takes the value of 1 for firms that were granted a R\&D fiscal deduction in period 1 (but not in period 0 ) and takes the value of 0 for firms that were not granted a R\&D fiscal deduction in both periods 1 and 0 (firms that were granted a R\&D fiscal deduction in period 0 are excluded from the analysis), $d_{1}$ is a dummy variable that takes the value of 1 in $t=1$ (the follow-up period) and 0 in $t=0$ (the base-line period), IT and NO are country specific dummy variables (with France as excluded category), $\mathrm{W}_{\mathrm{ijt}}, \mathrm{RD}_{\mathrm{j}}, \mathrm{C}_{\mathrm{j}}$ (defined as before) are firm-, time- and sector-specific control variables, and $u_{\mathrm{ijt}}$ is an idiosyncratic error term. In this baseline regression model, the coefficient of interest is $\eta$, which represents the difference in difference (DD) estimator of the treatment effect (Angrist and Pischke, 2008). The extended regression model for the cross-country DDD analysis (again with two periods: $\mathrm{t}=0,1$, and with full country specific effects) is the following:

$$
\begin{aligned}
& \mathrm{RDI}_{\mathrm{it}}=\alpha+\beta \text { Treated }_{\mathrm{i}}+\gamma \mathrm{d}_{1}+\eta\left(\text { Treated }_{\mathrm{ij}} \times \mathrm{d}_{1}\right)+\delta_{I T} \mathrm{IT}+\beta_{I T}\left(\text { Treated }_{\mathrm{ij}} \times \mathrm{IT}\right)+\gamma_{I T}\left(\mathrm{~d}_{1} \times \mathrm{IT}\right) \\
& +\eta_{I T}\left(\text { Treated }_{\mathrm{ij}} \times \mathrm{d}_{1} \times \mathrm{IT}\right)+\delta_{N O} \mathrm{NO}+\beta_{N O}\left(\text { Treated }_{\mathrm{ij}} \times \mathrm{NO}\right)+\gamma_{N O}\left(\mathrm{~d}_{1} \times \mathrm{NO}\right)+ \\
& \eta_{N O}\left(\text { Treated }_{\mathrm{ij}} \times \mathrm{d}_{1} \times \mathrm{NO}\right)+\theta \mathrm{W}_{\mathrm{ijt}}+\kappa \mathrm{RD}_{\mathrm{j}}+\lambda \mathrm{C}_{\mathrm{j}}+u_{\mathrm{ijt}}
\end{aligned}
$$

Both the baseline and the extended models are estimated using Weighted Least Squares with propensity-score weights computed following the methodology proposed by Nichols $(2007,2008)$. The first two panels on the top of Table 7 report the estimation results and the predicted values of $\mathrm{RDI}_{i t}$ for the baseline model (A1) when considering 
the years 2004-2006 (Panel A1) and 2006-2008 (Panel A2). Overall, the DD estimates of the impact of tax credits on R\&D intensity are positive and significant in both periods, with an estimated magnitude of the DD parameter $\eta$ for the period 2006-2008 that is two times larger than the one estimated for the period 2004-2006. Comparing the magnitude of the DD estimates across countries (Panels B1 to D2) retrieved from model (A2), we find a larger effect for Norway during the period 2004-2006, and for Italy during the period 2008-2006.

Table 8 reports the results of DDD estimates. These show that the larger input additionality effect for Norway (vis-a-vis France and Italy) in 2004-2006 (Panel A) is mainly driven by differences in $R \& D$ tax credits schemes among the three countries, since the cross-country difference in $\mathrm{R} \& \mathrm{D}$ intensity is significant only between recipient (Treated $=1$ ) firms whereas it is not significant between non-recipient companies (Treated $=0)$. Conversely, the larger $\mathrm{R} \& \mathrm{D}$ input additionality effect for Italy (vis-a-vis France and Norway) in 2006-2008 (Panel B) is explained by both differences in R\&D tax credit schemes among these economies, as well as other country-specific characteristics, since the cross-country differences in $\mathrm{R} \& \mathrm{D}$ intensity are significant both for recipient (Treated $=1)$ and non-recipient firms (Treated $=0$ ).

All in all, the main point of interest in these results is to show that input additionality effects have been significantly stronger in the two countries with a volume-based design - Norway and Italy - than in France, which adopted an incremental-based scheme (until the year 2008, when our investigation period ends). We discuss a possible interpretation of these findings in section 4. 
Table 7: Predicted values of $R D_{i t}$ and Diff-in-diff (DD) estimates (in bold) of input additionality effects (robust $t$-statistics in parentheses).

\begin{tabular}{|c|c|c|c|c|c|c|c|}
\hline \multicolumn{4}{|c|}{$\begin{array}{c}\text { Panel A1: All countries 2004-2006 } \\
\text { Model (A1) }\end{array}$} & \multicolumn{4}{|c|}{$\begin{array}{l}\text { Panel A2: All countries 2006-2008 } \\
\text { Model (A1) }\end{array}$} \\
\hline Baseline & $\mathrm{t} 0=$ & $\mathrm{t} 1=$ & $\operatorname{Diff}(\mathrm{t} 1-\mathrm{t} 0)$ & Baseline & $\mathrm{t} 0=$ & $\mathrm{t} 1=$ & $\operatorname{Diff}(\mathrm{t} 1-\mathrm{t} 0)$ \\
\hline model & 2004 & 2006 & & model & 2006 & 2008 & \\
\hline Treated $=0$ & 2.495 & 2.019 & -0.475 & Treated $=0$ & 2.704 & 2.975 & 0.271 \\
\hline $\mathrm{N}=1159$ & $(14.91)^{* * *}$ & $(12.04)^{* * *}$ & $(-2.00)^{* *}$ & $\mathrm{~N}=1410$ & $(8.26)^{* * *}$ & $(8.33)^{* * *}$ & $(0.56)$ \\
\hline Treated $=1$ & 2.575 & 3.065 & 0.490 & Treated $=1$ & 2.999 & 5.337 & 2.338 \\
\hline $\mathrm{N}=330$ & $(15.30)^{* * *}$ & $(18.30)^{* * *}$ & $(2.06)^{* *}$ & $\mathrm{~N}=227$ & $(9.16)^{* * *}$ & $(19.21)^{* * *}$ & $(5.42)^{* * *}$ \\
\hline \multicolumn{3}{|l|}{ Diff(Treated- } & Diff in Diff & Diff(Treated- & & & Diff in Diff \\
\hline \multirow[t]{2}{*}{ Untreated) } & 0.080 & 1.046 & 0.965 & Untreated) & 0.295 & 2.362 & 2.067 \\
\hline & $(0.34)$ & $(4.42)^{* * *}$ & $(2.88) * * *$ & & $(0.64)$ & $(5.22)^{* * *}$ & $(3.20) * * *$ \\
\hline \multicolumn{4}{|c|}{$\begin{array}{c}\text { Panel B1: France 2004-2006 } \\
\text { Model (A2) }\end{array}$} & \multicolumn{4}{|c|}{$\begin{array}{c}\text { Panel B2: France 2006-2008 } \\
\text { Model (A2) }\end{array}$} \\
\hline \multirow[t]{2}{*}{ France } & $\mathrm{t} 0=$ & $\mathrm{t} 1=$ & $\operatorname{Diff}(\mathrm{t} 1-\mathrm{t} 0)$ & France & $\mathrm{t} 0=$ & $\mathrm{t} 1=$ & $\operatorname{Diff}(\mathrm{t} 1-\mathrm{t} 0)$ \\
\hline & 2004 & 2006 & & & 2006 & 2008 & \\
\hline Treated $=0$ & 2.680 & 2.445 & -0.235 & Treated $=0$ & 4.405 & 3.480 & -0.924 \\
\hline $\mathrm{N}=455$ & $(12.24)^{* * *}$ & $(11.14)^{* * *}$ & $(-0.78)$ & $\mathrm{N}=415$ & $(7.33)^{* * *}$ & $(5.39)^{* * *}$ & $(-1.10)$ \\
\hline Treated $=1$ & 3.073 & 3.100 & 0.027 & Treated $=1$ & 5.164 & 5.001 & -0.163 \\
\hline $\mathrm{N}=199$ & $(13.80)^{* * *}$ & $(13.98)^{* * *}$ & $(0.09)$ & $\mathrm{N}=75$ & $(8.27)^{* * *}$ & $(10.00)^{* * *}$ & $(-0.21)$ \\
\hline \multicolumn{2}{|c|}{ Diff(Treated- } & & Diff in Diff & Diff(Treated- & & & Diff in Diff \\
\hline \multirow[t]{2}{*}{ Untreated) } & 0.392 & 0.655 & 0.262 & Untreated) & 0.760 & 1.521 & 0.761 \\
\hline & $(1.29)$ & $(2.16)^{* *}$ & $(0.61)$ & & $(0.90)$ & $(1.95)^{*}$ & $(0.66)$ \\
\hline \multicolumn{4}{|c|}{$\begin{array}{c}\text { Panel C1: Italy 2004-2006 } \\
\text { Model (A2) }\end{array}$} & \multicolumn{4}{|c|}{$\begin{array}{c}\text { Panel C2: Italy 2006-2008 } \\
\text { Model (A2) }\end{array}$} \\
\hline \multirow[t]{2}{*}{ Italy } & $\mathrm{t} 0=$ & $\mathrm{t} 1=$ & $\operatorname{Diff}(\mathrm{t} 1-\mathrm{t} 0)$ & Italy & $\mathrm{t} 0=$ & $\mathrm{t} 1=$ & $\operatorname{Diff}(\mathrm{t} 1-\mathrm{t} 0)$ \\
\hline & 2004 & 2006 & & & 2006 & 2008 & \\
\hline Treated $=0$ & 2.898 & 1.469 & -1.429 & Treated $=0$ & 0.522 & 2.940 & 2.418 \\
\hline $\mathrm{N}=312$ & $(7.01)^{* * *}$ & $(3.55)^{* * *}$ & $(-2.47)^{* *}$ & $\mathrm{~N}=257$ & $(0.91)$ & $(5.13)^{* * *}$ & $(3.05)^{* * *}$ \\
\hline Treated $=1$ & 1.445 & 1.139 & -0.306 & Treated $=1$ & 1.749 & 7.371 & 5.622 \\
\hline $\mathrm{N}=54$ & $(3.42)^{* * *}$ & $(2.68)^{* * *}$ & $(-0.52)$ & $\mathrm{N}=75$ & $(3.37)^{* * *}$ & $(15.19)^{* * *}$ & $(7.92)^{* * *}$ \\
\hline \multicolumn{3}{|l|}{ Diff(Treated- } & Diff in Diff & Diff(Treated- & & & Diff in Diff \\
\hline \multirow[t]{2}{*}{ Untreated) } & -1.453 & -0.330 & 1.123 & Untreated) & 1.227 & 4.431 & 3.204 \\
\hline & $(-2.49)^{* *}$ & $(-0.57)$ & (1.37) & & $(1.62)$ & $(5.97)^{* * *}$ & $(3.07) * * *$ \\
\hline \multicolumn{4}{|c|}{$\begin{array}{c}\text { Panel D1: Norway 2004-2006 } \\
\text { Model (A2) }\end{array}$} & \multicolumn{4}{|c|}{$\begin{array}{l}\text { Panel D2: Norway 2006-2008 } \\
\text { Model (A2) }\end{array}$} \\
\hline \multirow[t]{2}{*}{ Norway } & $\mathrm{t} 0=$ & $\mathrm{t} 1=$ & $\operatorname{Diff}(\mathrm{t} 1-\mathrm{t} 0)$ & Norway & $\mathrm{t} 0=$ & $\mathrm{t} 1=$ & $\operatorname{Diff}(\mathrm{t} 1-\mathrm{t} 0)$ \\
\hline & 2004 & 2006 & & & 2006 & 2008 & \\
\hline Treated $=0$ & 1.706 & 1.306 & -0.401 & Treated $=0$ & 3.220 & 2.570 & -0.650 \\
\hline $\mathrm{N}=392$ & $(4.76) * * *$ & $(3.66)^{* * *}$ & $(-0.82)$ & $\mathrm{N}=738$ & $(5.74)^{* * *}$ & $(3.82)^{* * *}$ & $(-0.75)$ \\
\hline Treated $=1$ & 2.082 & 4.333 & 2.251 & Treated $=1$ & 2.506 & 3.896 & 1.391 \\
\hline $\mathrm{N}=77$ & $(5.85)^{* * *}$ & $(12.29)^{* * *}$ & $(4.61)^{* * *}$ & $\mathrm{~N}=77$ & $(4.35)^{* * *}$ & $(8.30)^{* * *}$ & $(1.89)^{*}$ \\
\hline \multirow{3}{*}{$\begin{array}{l}\text { Diff(Treated- } \\
\text { Untreated) }\end{array}$} & & & Diff in Diff & Diff(Treated- & & & Diff in Diff \\
\hline & 0.376 & 3.028 & 2.652 & Untreated) & -0.714 & 1.326 & 2.040 \\
\hline & $(0.77)$ & $(6.20)^{* * *}$ & $(3.85) * * *$ & & $(-0.90)$ & $(1.62)$ & $(1.79) *$ \\
\hline
\end{tabular}


Table 8: Diff-in-diff-in-diff (DDD) estimates: comparison of input additionality effects across countries.

\begin{tabular}{|c|c|c|c|c|c|c|c|}
\hline \multicolumn{4}{|c|}{$\begin{array}{c}\text { Panel A: 2004-2006 } \\
\text { Model (A2) }\end{array}$} & \multicolumn{4}{|c|}{$\begin{array}{c}\text { Panel B: 2006-2008 } \\
\text { Model (A2) }\end{array}$} \\
\hline $\operatorname{Diff}(\mathrm{t} 1-\mathrm{t} 0)$ & FR-IT & FR-NO & IT-NO & $\operatorname{Diff}(\mathrm{t} 1-\mathrm{t} 0)$ & FR-IT & FR-NO & IT-NO \\
\hline \multirow[t]{2}{*}{ Treated $=0$} & 1.194 & 0.166 & -1.029 & Treated $=0$ & -3.343 & -0.275 & 3.068 \\
\hline & $(1.83)^{*}$ & $(0.29)$ & $(-1.36)$ & & $(-2.8)^{* * *}$ & $(-0.23)$ & $(2.60)^{* * *}$ \\
\hline Treated $=1$ & $\begin{array}{l}0.333 \\
(0.51)\end{array}$ & $\begin{array}{c}-2.224 \\
(-3.88)^{* * *}\end{array}$ & $\begin{array}{c}-2.557 \\
(-3.36)^{* * *}\end{array}$ & Treated $=1$ & $\begin{array}{c}-5.785 \\
(-5.51)^{* * *}\end{array}$ & $\begin{array}{l}-1.554 \\
(-1.46)\end{array}$ & $\begin{array}{c}4.231 \\
(4.13)^{* * *}\end{array}$ \\
\hline
\end{tabular}

Robust t-statistics in parenthesis. 